\title{
Targeted nanosystems: Advances in targeted dendrimers for cancer
}

\section{therapy}

Submitted to "Targeted Nanosystems as Therapeutic and Diagnostic Tools" Special Section

$$
\text { Hu Yang }{ }^{1,2,3, *}
$$

${ }^{1}$ Department of Chemical and Life Science Engineering, Virginia Commonwealth University, Richmond, Virginia 23284, USA

${ }^{2}$ Department of Pharmaceutics, Virginia Commonwealth University, Richmond, Virginia 23298, USA

${ }^{3}$ Massey Cancer Center, Virginia Commonwealth University, Richmond, Virginia 23298, USA

*Correspondence should be addressed to Hu Yang, Department of Chemical and Life Science Engineering, Virginia Commonwealth University, 401 West Main Street, P.O. Box 843067, Richmond, VA 23284, USA. Tel.: 1-804-828-5459; Fax: 1-804-828-4454; Email:hyang2@vcu.edu.

This work was supported, in part, by the National Science Foundation (CAREER award CBET0954957), National Institutes of Health (R01EY024072), and Virginia Commonwealth University Massey Cancer Center (multi-investigator award 2013-MIP-01).

Word count for abstract: 92; word count for manuscript including body text and figure legends: 2380; number of references: 49; number of figures: 8 


\begin{abstract}
Dendrimers possess discrete highly compact nanostructures constituted of successive branched layers. Soon after the inception of dendrimers, recognition of their tunable structures and biologically favorable properties provoked a great enthusiasm in delving deeply into the utility of dendrimers for biomedical and pharmaceutical applications. One of the most important nanotechnology applications is the development of nanomedicines for targeted cancer therapies. Tremendous success in targeted therapies has been achieved with the use of dendrimer-based nanomedicines. This article provides a concise review on latest advances in the utility of dendrimers in immunotherapies and hormone therapies.
\end{abstract}

Keywords: dendrimer, critical nanoscale design parameters, immunotherapy, hormone therapy 


\section{Introduction}

Dendrimers possess discrete highly compact nanostructures constituted of successive branched layers, which are commonly referred to as generations. ${ }^{1,2}$ Accompanying dendrimer generation increase, the number of branches and surface groups increases exponentially along with a stepwise increase in size. Soon after the inception of dendrimers, recognition of their tunable structures and biologically favorable properties provoked a great enthusiasm in delving deeply into the utility of dendrimers for biomedical and pharmaceutical applications. ${ }^{3,4}$ Dendrimers offer a high degree of flexibility in drug loading. Drugs can be either covalently conjugated to the dendrimer surface ${ }^{5-10}$ or physically encapsulated into the inner core. ${ }^{11-13}$ Gene plasmids and nucleic acids can be complexed with dendrimers through electrostatic

interaction. ${ }^{14-21}$ Burgeoning evidence shows that dendrimers empower development of effective theranostic platforms as supported by numerous in vitro and pre-clinical studies. Intense efforts have been invested in developing dendrimer-based nanomedicines and translating them into clinical applications. ${ }^{2}$ A few dendrimer-based nanomedicine products such as VivaGel@-a new antimicrobial agent- have been successfully commercialized. Those with encouraging preclinical results, for example, Starpharma's dendrimer-enhanced docetaxel (commonly known as DEPTM docetaxel), have moved to clinical trials or are in the pipeline for FDA regulatory approval reviews.

There is a widespread interest in diverse topics ranging from synthesis and functionalization of dendrimers, design principles and considerations for the utility of dendrimer features, to dendrimer-based drug delivery systems for treatment of various diseases. ${ }^{22-24}$ One of the most important nanotechnology applications is the development of nanomedicines for targeted cancer therapies. Different from conventional chemotherapy acting on rapidly dividing 
normal and cancerous cells, targeted therapies interfere with specific molecular targets that are involved in cancer growth, progression, and spread. Tremendous success in targeted therapies has been achieved with the use of dendrimer-based nanomedicines. Targeted therapies have been grouped to different categories including hormone therapies, signal transduction inhibitors, gene therapy, apoptosis inducer, angiogenesis inhibitor, immunotherapies, and toxin delivery molecules. This article provides a concise review on latest advances in the utility of dendrimers in immunotherapies and hormone therapies.

\section{Dendrimer nanomedicine design considerations: critical nanoscale design parameters (CNDPs)}

Critical nanoscale design parameters (CNDPs), namely size, shape, surface chemistry, flexibility/rigidity, elemental composition, and architecture, have been applied to establish a nanoperiodic framework to understand nanoparticle structure control and atom-like combining

properties of dendrimers. ${ }^{2,25}$ It is gaining increasing recognition that pharmacokinetics, pharmacodynamics, and toxicokinetics of nanomedicines in preclinical and clinical are also influenced by the CNDPs mentioned above. Uniquely, dendrimers offer defined nanostructures that can be engineered through any one of the six CNDPs (Figure 1). Therefore, CNDP-directed design strategies can be implemented to develop dendrimer-based nanomedicines and offer a powerful tool for elucidation of structure-property-function relationships and optimization of the nanomedicines in the context of intended clinical applications (Figure 1). ${ }^{2}$

It is worth noting that clearance pathway of PAMAM dendrimers shows clear size (or generation)- and charge-dependence. ${ }^{2,26}$ PAMAM dendrimers of generation 5 or lower can be sufficiently eliminated via glomerular filtration in the pathway of renal excretion. However, 
when size of dendrimers is close to the filtration size threshold, charge plays a significant role. The highly negatively charged glomerular basement membrane makes it more difficult for anionic dendrimers to filtrate. As dendrimers become larger in size, their elimination relies on hepatic clearance. Dendrimer surface functionalization often leads to size increase and charge changes. Such design parameters will help predict in vivo biodistribution and clearance patterns of dendrimer nanomedicine and create more effective delivery systems.

\section{Dendrimer-ligand conjugates for tumor cell targeting}

Immunotherapies may harness the immune system to attack cancer cells with the aid of dendrimers. One strategy is to prepare immunodendrimers by surface functionalizing dendrimers with monoclonal antibodies (mAbs) that bind to the surface of cancer cells. The multivalency and hydrophobic inner core of dendrimers can then be utilized to deliver toxic molecules through covalent conjugation and encapsulation, respectively, to kill cancer cells precisely with guidance of the conjugated mAbs.

Over $70 \%$ of ovarian adenocarcinoma overly express mesothelin, a glycosyl-phosphatidyl inositol (GPI)-linked membrane protein, which can be recognized by monoclonal antibody K1 (mAbK1). Immunodendrimers were made towards ovarian cancer treatment by conjugating mAbK1 to half-generation poly (propylene imine) (PPI) dendrimers (Figure 2). Paclitaxel (PTX) was encapsulated into the hydrophobic nanodomains of PPI dendrimers. Nearly $30 \%$ of the drug was entrapped in dendrimers at a drug to dendrimer ratio of 4:1. The resulting mAbK1-PPI-PTX was tested in an ovarian cancer model, and it was found to reduce tumor volume and extend animal survival more significantly through enhanced drug uptake in the tumor. ${ }^{27}$ 
In most cases, cancer cells express much higher levels of receptors on the cell surface, such as folate receptor, EGFR. In addition to mAbs, ligands that bind to those receptors can be conjugated to the dendrimer to make targeted dendrimers. It has been widely accepted that multivalent conjugation of folic acid to the dendrimers makes the conjugates have high avidity to folate binding protein. In one of our latest publications, we reported functionalization of dendrimers with EGF peptide ligands for EGFR-mediated gene delivery. ${ }^{17}$ In this particular system, the dendrimer surface was uniformly coated with triglycine (GGG) spacer for improving cytocompatibility while maintaining positive charges for complexation with nucleic acids (Figure 3). Quantum dots were conjugated to the dendrimer via a polyethylene glycol (PEG) spacer for imaging purpose. Vimentin shRNA (shVIM) and yellow fluorescent protein (YFP) siRNA can be delivered to head and neck cancer cells HN12 cells more efficiently to exert knockdown effects. Selectivity of the EGF-conjugated dendrimers against tumor cells was also demonstrated.

Most recently, van Dongen et al. creatively synthesized a monovalent folic aciddendrimer conjugate using click chemistry. ${ }^{28}$ They used the synthesized monovalent folic aciddendrimer conjugate to study how the folic acid-polymer conjugate binds to a folate binding protein surface. Their seminal work showed that monovalent folic acid-dendrimer conjugate also has increased avidity, and they argued that the increased avidity results from a two-phase folatekeyed interaction: an initial, reversible, FA concentration dependent key-lock/van der Waals binding between the conjugate and protein, and then an irreversible interaction between the dendrimer and protein surfaces (Figure 4, model C). Their findings provide new insight into rational design of targeted dendrimers based upon the utility of multivalency of dendrimers.

\section{Dendrimer-antigen conjugates for immune response stimulation}


Dendritic cells (DCs) are antigen presenting cells of the immune system. DCs present antigens to $\mathrm{T}$ cells and initiate the immune response as illustrated in Figure $5 .{ }^{29}$ In recognition of the importance of DCs in immunotherapy, tumor-associated antigens (TAAs) and adjuvants can be simultaneously or respectively loaded onto nanoparticles and taken up by the same DC to initiate the immune response through coordinated activation. In particular, TAAs presented via major histocompatibilitycomplex (MHC) class I and class II molecules can be recognized by CD8+ and CD4+ naïve T cells through T-cell receptors (TCRs). Activated CD8+ T cells differentiate into memory $\mathrm{T}$ cells and cytotoxic $\mathrm{T}$ lymphocytes (CTLs) that are responsible for killing tumor cells. In the meantime, CD4+ T cells differentiate in type $1 \mathrm{~T}$ helper (Th1) cells, which help potentiate the action of CTLs and activate those cells of the innate immune system, such as natural killer (NK) cells, granulocytes and macrophages to strengthen tumor destruction process.

As discussed above, delivery of antigens to DCs is a critical step for successfully triggering immune response but antigen delivery efficiency is rather limited. Dendrimers were recently biofunctionalized to enhance efficiency of antigen delivery to dendritic cells. ${ }^{30}$ DCSIGN (dendritic cell-specific ICAM-3-grabbing non-integrin) is a C-type lectin receptor present on the surface of DCs and can be targeted for antigen delivery to DCs. Lewis ${ }^{\mathrm{b}}\left(\mathrm{Le}^{\mathrm{b}}\right)$ glycopeptides are natural ligands that bind to DC-SIGN. In this work, $\mathrm{Le}^{\mathrm{b}}$ was conjugated to the dendrimer surface (Figure 6). Interestingly, an increase in DC-SIGN ligand multivalency directly results in linearly enhanced binding.

\section{Dendrimer-cell hybrids}


The ability of anticancer drugs to precisely attack cancer cells influences cancer treatment effectiveness. Although nanostructured materials and cells have been actively researched as carriers for drug delivery, each type has its distinct advantages as well as apparent limitations in terms of anticancer drug delivery. Heterogeneities of vascular permeability and the complex microenvironment of cancer biology are barriers for effective delivery of drug-carrying nanoparticles including those decorated with tumor-specific ligand relies heavily on passive mechanisms such as the enhanced permeability and retention (EPR) effect. Only a small percentage of the injected drug can finally accumulate in the tumor with the aid of nanoparticles, in large part, due to rapid clearance by immune cells in the liver and spleen. Using cells to deliver drugs has also attracted considerable attention. Immune cells including T cells and macrophages have built-in cancer-targeting or-attacking abilities and seem suitable for anticancer drug delivery because they respond to tumor invasion, recurrence, and metastasis or tumor hypoxia and actively infiltrate in the tumor. ${ }^{31-38}$ Such cellular vehicles with have a great potential to deliver therapeutic compounds. Nonetheless, none of the approaches mentioned above is applicable to cell-based anticancer drug delivery. Anticancer drugs cannot be directly loaded into the cellular vehicle or loosely encapsulated on the cell surface because of the detrimental impact of their inherent toxicity on cell viability and functions. Resolution of this issue is critical to the realization of the potential of this therapeutic approach.

Yang's team developed a delivery platform by hybridizing immune cell and dendrimers via highly efficient highly selective bioorthogonal reaction on the cell surface (Figure 7). ${ }^{39}$ The resulting hybrids remained good viability and motility, indicating the mildness of the chemistry and noninvasiveness to the cellular vehicle. This hybrid system takes advantage of multivalency of PAMAM dendrimers for delivery of compounds of interest such as drugs and imaging agents. 
This approach provides a new way to utilize dendrimers and immune cells and make it possible to develop personalized immunotherapy.

\section{Dendrimer-based hormone therapy}

Hormone therapies exert therapeutic effectiveness by preventing production of hormones or impeding hormone activities. ${ }^{40}$ Similar to other cancer types, receptors that are overexpressed can be utilized to develop targeted therapy. For instance, elevated expression of follicle stimulating hormone receptor (FSHR) in ovarian cancers has been confirmed. ${ }^{41,42}$ Thus, targeted ovarian cancer therapy can be achieved by designing drug delivery systems carrying FSH ligand. Recently, Modi et al. designed a dendrimer-based platform to target FSHR. The platform was constructed by coupling the binding peptide domain of FSH (FSH33) to PAMAM dendrimer G5.0 (Figure 8). ${ }^{43}$ The high selectivity of FSH33-dendrimer conjugates was confirmed. Furthermore, the conjugates displayed receptor antagonistic effect by downregulating surviving, an anti-apoptotic protein.

\section{Conclusions and outlook}

High-quality dendrimer products in high quantities have been made available for fundamental research and translational studies owing to commercialization of PAMAM dendrimers by several companies such as Dendritech (Midland, Michigan) and NanoSynthons (Mt. Pleasant, Michigan). The commercially available dendrimers serve as a reliable source of building blocks for development of dendrimer nanomedicine products on a large scale. Nonetheless, manufacturing of functionalized dendrimers with uniform loading of drugs, ligands, and other moieties on the dendrimer surface is challenging and remains to be solved for consistent therapeutic effects. ${ }^{44}$ Efficient and robust dendrimer surface chemistries such as click 
chemistry ${ }^{45}$ must be developed to tackle the heterogeneity of dendrimer surface functionalization and enable scaling up of dendrimer nanomedicine products. Factors

Cancer therapy strategies have diversified considerably. Mechanisms for cancer therapies also include blockage of signal transduction inhibitor activities, modulation of gene expression, induction of apoptosis, inhibition of angiogenesis and utility of cancer vaccines. Nanostructured carriers including dendrimers are expected to continue to play an important role in delivering payload to the right target at the tissue, cellular, or subcellular levels. Interesting and astonishing biological activities of dendrimers, particularly PAMAM dendrimers, have been revealed lately. In particular, PAMAM dendrimers show anti-inflammatory activities via different mechanisms determined by surface groups ${ }^{46,47}$ Neutral dendrimers have been found to target inflammatory cells within the brain. They can localize in activated microglia and astrocytes in the presence of neuroinflammation. ${ }^{48}$ Activated (i.e., SuperFect) and non-activated (i.e., Polyfect) PAMAM dendrimers can differentially modulate EGFR signaling pathway. ${ }^{49}$ Such intrinsic therapeutic functions endowed by dendrimers themselves may be integrated into drug delivery system design and offer additional therapeutic benefits for cancer therapy. 


\section{References}

1 D. A. Tomalia, H. Baker, J. Dewald, M. Hall, G. Kallos, S. Martin, et al., Dendritic macromolecules: synthesis of starburst dendrimers. Macromolecules. 1986;19:2466-8.

2 R. M. Kannan, E. Nance, S. Kannan and D. A. Tomalia, Emerging concepts in dendrimer-based nanomedicine: from design principles to clinical applications. $J$ Intern Med. 2014;276:579-617.

3 M. Liu and J. M. J. Frechet, Designing dendrimers for drug delivery. Pharmaceutical Science \& Technology Today. 1999;2:393-401.

4 S. Svenson and D. A. Tomalia, Dendrimers in biomedical applications--reflections on the field. Adv Drug Deliv Rev. 2005;57:2106-29.

5 H. Yang and S. T. Lopina, Stealth dendrimers for antiarrhythmic quinidine delivery. $J$. Mater. Sci.: Mater. Med. 2007;18:2061-2065.

6 H. Yang and S. T. Lopina, In vitro enzymatic stability of dendritic peptides. J Biomed Mater Res, Part A. 2006;76A:398-407.

7 H. Yang and S. T. Lopina, Extended release of a novel antidepressant, venlafaxine, based on anionic polyamidoamine dendrimers and poly(ethylene glycol)-containing semiinterpenetrating networks. J Biomed Mater Res. 2005;72A:107-14.

8 H. Yang and S. T. Lopina, Penicillin V-conjugated PEG-PAMAM star polymers. $J$ Biomater Sci Polym Ed. 2003;14:1043-56. 
9 W. C. She, D. Y. Pan, K. Luo, B. He, G. Cheng, C. Y. Zhang, et al., PEGylated Dendrimer-Doxorubicin Cojugates as pH-Sensitive Drug Delivery Systems: Synthesis and In Vitro Characterization. Journal of Biomedical Nanotechnology. 2015;11:964-978.

10 S. J. Lee, Y. I. Jeong, H. K. Park, D. H. Kang, J. S. Oh, S. G. Lee, et al., Enzymeresponsive doxorubicin release from dendrimer nanoparticles for anticancer drug delivery. Int J Nanomed. 2015;10:5489-5503.

11 H. Yang, J. J. Morris and S. T. Lopina, Polyethylene glycol-polyamidoamine dendritic micelle as solubility enhancer and the effect of the length of polyethylene glycol arms on the solubility of pyrene in water. J. Colloid Interface Sci. 2004;273:148-154.

12 K. Sarkar and H. Yang, Encapsulation and extended release of anti-cancer anastrozole by stealth nanoparticles. Drug Deliv. 2008;15:343-6.

13 J. Y. Zhu, Z. J. Xiong, M. W. Shen and X. Y. Shi, Encapsulation of doxorubicin within multifunctional gadolinium-loaded dendrimer nanocomplexes for targeted theranostics of cancer cells. Rsc Adv. 2015;5:30286-30296.

14 C. Z. Bai, S. Choi, K. Nam, S. An and J. S. Park, Arginine modified PAMAM dendrimer for interferon beta gene delivery to malignant glioma. Int J Pharm. 2013;445:79-87.

15 M. K. Mishra, H. C. Gerard, J. A. Whittum-Hudson, A. P. Hudson and R. M. Kannan, Dendrimer-enabled modulation of gene expression in Chlamydia trachomatis. Mol Pharm. 2012;9:413-21. 
16 A. C. Rodrigo, I. Rivilla, F. C. Perez-Martinez, S. Monteagudo, V. Ocana, J. Guerra, et al., Efficient, non-toxic hybrid PPV-PAMAM dendrimer as a gene carrier for neuronal cells. Biomacromolecules. 2011;12:1205-13.

17 Q. Yuan, E. Lee, W. A. Yeudall and H. Yang, Dendrimer-triglycine-EGF nanoparticles for tumor imaging and targeted nucleic acid and drug delivery. Oral Oncol. 2010;46:698704.

18 Q. Yuan, W. A. Yeudall and H. Yang, PEGylated polyamidoamine dendrimers with bisaryl hydrazone linkages for enhanced gene delivery. Biomacromolecules. 2010;11:19407.

19 Q. Yuan, W. A. Yeudall and H. Yang, Thermoresponsive Dendritic Facial Amphiphiles for Gene Delivery. Nanomedicine and Nanobiology. 2014;1:64-69.

20 L. M. Guan, S. P. Huang, Z. Chen, Y. C. Li, K. Liu, Y. Liu, et al., Low cytotoxicity fluorescent PAMAM dendrimer as gene carriers for monitoring the delivery of siRNA. $J$ Nanopart Res. 2015;17

21 S. Xiao, R. Castro, J. Rodrigues, X. Y. Shi and H. Tomas, PAMAM Dendrimer/pDNA Functionalized-Magnetic Iron Oxide Nanoparticles for Gene Delivery. Journal of Biomedical Nanotechnology. 2015;11:1370-1384.

22 H. Yang and W. J. Kao, Dendrimers for pharmaceutical and biomedical applications. $J$ Biomater Sci Polym Ed. 2006;17:3-19. 
23 H. Yang, Nanoparticle-mediated brain-specific drug delivery, imaging, and diagnosis. Pharm Res. 2010;27:1759-71.

24 X. Leyuan, W. A. Yeudall and Y. Hu, 2013. Dendrimer-Based RNA Interference Delivery for Cancer Therapy Tailored Polymer Architectures for Pharmaceutical and Biomedical Applications, American Chemical Society, pp 197-213

25 D. A. Tomalia, Dendrons/dendrimers: quantized, nano-element like building blocks for soft-soft and soft-hard nano-compound synthesis. Soft Matter. 2010;6:456-474.

26 M. Longmire, P. L. Choyke and H. Kobayashi, Clearance properties of nano-sized particles and molecules as imaging agents: considerations and caveats. Nanomedicine (Lond). 2008;3:703-17.

27 N. K. Jain, M. S. Tare, V. Mishra and P. K. Tripathi, The development, characterization and in vivo anti-ovarian cancer activity of poly(propylene imine) (PPI)-antibody conjugates containing encapsulated paclitaxel. Nanomedicine. 2015;11:207-18.

28 M. A. van Dongen, J. E. Silpe, C. A. Dougherty, A. K. Kanduluru, S. K. Choi, B. G. Orr, et al., Avidity mechanism of dendrimer-folic acid conjugates. Mol Pharm. 2014;11:1696706.

29 J. Conniot, J. M. Silva, J. G. Fernandes, L. C. Silva, R. Gaspar, S. Brocchini, et al., Cancer immunotherapy: nanodelivery approaches for immune cell targeting and tracking. Front Chem. 2014;2:105. 
30 J. J. Garcia-Vallejo, M. Ambrosini, A. Overbeek, W. E. van Riel, K. Bloem, W. W. Unger, et al., Multivalent glycopeptide dendrimers for the targeted delivery of antigens to dendritic cells. Mol Immunol. 2013;53:387-97.

31 W. H. Fridman, F. Pages, C. Sautes-Fridman and J. Galon, The immune contexture in human tumours: impact on clinical outcome. Nat Rev Cancer. 2012;12:298-306.

32 J. M. Brown and W. R. Wilson, Exploiting tumour hypoxia in cancer treatment. Nat. Rev. Cancer. 2004;4:437-47.

33 L. Griffiths, K. Binley, S. Iqball, O. Kan, P. Maxwell, P. Ratcliffe, et al., The macrophage - a novel system to deliver gene therapy to pathological hypoxia. Gene Ther. 2000;7:255-62.

34 S. Paul, D. Snary, J. Hoebeke, D. Allen, J. M. Balloul, N. Bizouarne, et al., Targeted macrophage cytotoxicity using a nonreplicative live vector expressing a tumor-specific single-chain variable region fragment. Hum Gene Ther. 2000;11:1417-28.

35 I. Mellman, G. Coukos and G. Dranoff, Cancer immunotherapy comes of age. Nature. 2011;480:480-9.

36 N. P. Restifo, M. E. Dudley and S. A. Rosenberg, Adoptive immunotherapy for cancer: harnessing the T cell response. Nat Rev Immunol. 2012;12:269-81.

37 M. R. Choi, K. J. Stanton-Maxey, J. K. Stanley, C. S. Levin, R. Bardhan, D. Akin, et al., A cellular Trojan Horse for delivery of therapeutic nanoparticles into tumors. Nano Lett. 2007;7:3759-65. 
38 M. T. Stephan, J. J. Moon, S. H. Um, A. Bershteyn and D. J. Irvine, Therapeutic cell engineering with surface-conjugated synthetic nanoparticles. Nat Med. 2010;16:1035-41.

39 L. Xu, O. Y. Zolotarskaya, W. A. Yeudall and H. Yang, Click hybridization of immune cells and polyamidoamine dendrimers. Adv Healthc Mater. 2014;3:1430-8.

40 W. R. Harrington, S. H. Kim, C. C. Funk, Z. Madak-Erdogan, R. Schiff, J. A. Katzenellenbogen, et al., Estrogen dendrimer conjugates that preferentially activate extranuclear, nongenomic versus genomic pathways of estrogen action. Mol Endocrinol. 2006;20:491-502.

41 C. K. Bose, Follicle stimulating hormone receptor in ovarian surface epithelium and epithelial ovarian cancer. Oncol Res. 2008;17:231-8.

42 J. H. Choi, K. C. Choi, N. Auersperg and P. C. Leung, Overexpression of folliclestimulating hormone receptor activates oncogenic pathways in preneoplastic ovarian surface epithelial cells. J Clin Endocrinol Metab. 2004;89:5508-16.

43 D. A. Modi, S. Sunoqrot, J. Bugno, D. D. Lantvit, S. Hong and J. E. Burdette, Targeting of follicle stimulating hormone peptide-conjugated dendrimers to ovarian cancer cells. Nanoscale. 2014;6:2812-20.

44 X. Y. Shi, I. J. Majoros, A. K. Patri, X. D. Bi, M. T. Islam, A. Desai, et al., Molecular heterogeneity analysis of poly(amidoamine) dendrimer-based mono- and multifunctional nanodevices by capillary electrophoresis. Analyst. 2006;131:374-381. 
45 O. Y. Zolotarskaya, L. Y. Xu, K. Valerie and H. Yang, Click synthesis of a polyamidoamine dendrimer-based camptothecin prodrug. Rsc Adv. 2015;5:58600-58608.

46 Y. Tang, Y. Han, L. Liu, W. Shen, H. Zhang, Y. Wang, et al., Protective effects and mechanisms of G5 PAMAM dendrimers against acute pancreatitis induced by caerulein in mice. Biomacromolecules. 2015;16:174-82.

47 A. S. Chauhan, P. V. Diwan, N. K. Jain and D. A. Tomalia, Unexpected in vivo antiinflammatory activity observed for simple, surface functionalized poly(amidoamine) dendrimers. Biomacromolecules. 2009;10:1195-202.

48 H. Dai, R. S. Navath, B. Balakrishnan, B. R. Guru, M. K. Mishra, R. Romero, et al., Intrinsic targeting of inflammatory cells in the brain by polyamidoamine dendrimers upon subarachnoid administration. Nanomedicine (Lond). 2010;5:1317-29.

49 S. Akhtar, B. Al-Zaid, A. Z. El-Hashim, B. Chandrasekhar, S. Attur, M. H. Yousif, et al., Cationic Polyamidoamine Dendrimers as Modulators of EGFR Signaling In Vitro and In Vivo. PLoS One. 2015;10:e0132215. 


\section{Legends}

Figure 1. A schematic illustration of dendrimer critical nanoscale design parameter control and engineering for optimizing prototypes suitable for various nanomedical applications. (i) Size control (approximately $1 \mathrm{~nm}$ per generation) with mathematically defined polyvalent surface functionality; (ii) polyvalent dendrimer surface chemistry can be chemically partitioned into imaging groups (A), therapy with cleavable linkers (B), targeting groups (C) and biocompatible or circulatory enhancement groups $(Z)$. Cited from reference ${ }^{2}$ with permission.

Figure 2. (A) Pictorial presentation. (B) Molecular model of PTX loaded immunodendrimer (representation — red circle for oxygen; blue for nitrogen; white for hydrogen, and gray for carbon atom). Cited from reference ${ }^{27}$ with permission.

Figure 3. (A) EGF-triglycine (GGG)-dendrimer conjugates, (B) EGF-triglycine-dendrimer conjugates labeled with Qdots which were coated with amine-derivatized PEG. Cited from reference ${ }^{17}$ with permission.

Figure 4. Proposed models for enhanced G5-FA binding to FBP. (a) Multivalent binding increases avidity with increasing valency. (b) Any multivalent binding (2 or more interactions) is irreversible, and monovalent binding is reversible. (c) FA "keys" the initial interaction between conjugate and FBP, which is followed by strong nonspecific interaction between the dendrimer and protein. $\mathrm{C}$ represents $\mathrm{G} 5-\mathrm{FA}_{n}$ conjugate, $\mathrm{P}$ is $\mathrm{FBP}, \mathrm{CP}$ a complex between a conjugate and $n$ $\geq 1 \mathrm{FBP} . \mathrm{CP} *$ is a tight complex formed by a conformation change in the polymer and the resulting polymer-protein interaction. $\mathrm{C}$ represents $\mathrm{G} 5-$ Fan conjugate, $\mathrm{P}$ is FBP, CP a complex between a conjugate and $\mathrm{n} \geq 1 \mathrm{FBP}$. $\mathrm{CP}^{*}$ is a tight complex formed by a conformation change in 
the polymer and the resulting polymer-protein interaction. Cited from reference ${ }^{28}$ with permission.

Figure 5. Nanoparticle-based cancer vaccines can be targeted to DCs in vivo and after their internalization induce the maturation of these cells. Cited from reference ${ }^{29}$ with permission.

Figure 6. Multivalency enhances avidity of DC-SIGN for its ligands. Glycopeptide dendrimers are synthesized sequentially over PAMAM dendrimers functionalized with primary amines. A maleimide linker is used to attach the C-terminal Cys of the CKOTI/II peptide to the dendrimer. At the other end a glycan is attached to the $\mathrm{N}$-terminus via reductive amination to the side chain of a Lys. Adapted from reference ${ }^{30}$ with permission.

Figure 7. Click hybridization of immune cells and polyamidoamine dendrimers. Cited from reference ${ }^{39}$ with permission.

Figure 8. FSH33-targeted G5 PAMAM dendrimer conjugates. Cited from reference ${ }^{43}$ with permission. 


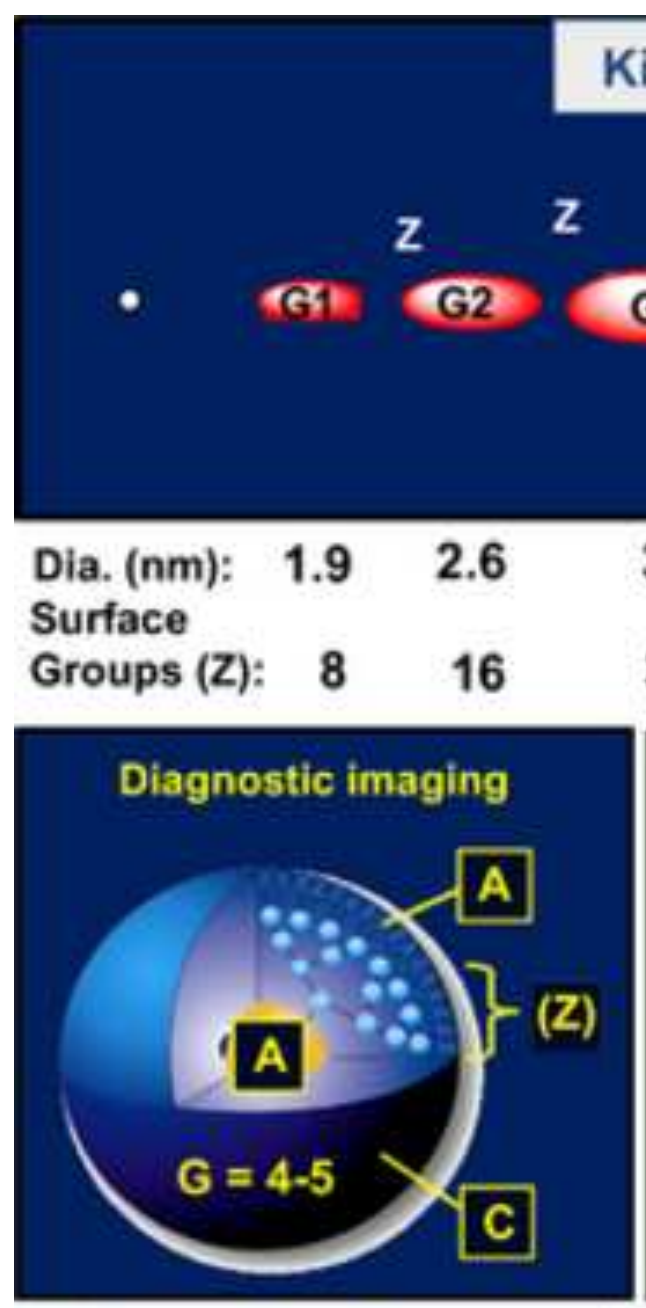

A Imaging Groups -Magnevist@ (MRI) - Near Infrared (NIR) -Fluorescein, Cy5 -Radionucleotides

\begin{tabular}{lll|l}
3.6 & 4.4 & 5.7 & 7.2
\end{tabular}

$\begin{array}{lll}32 & 64 & 128\end{array}$

256

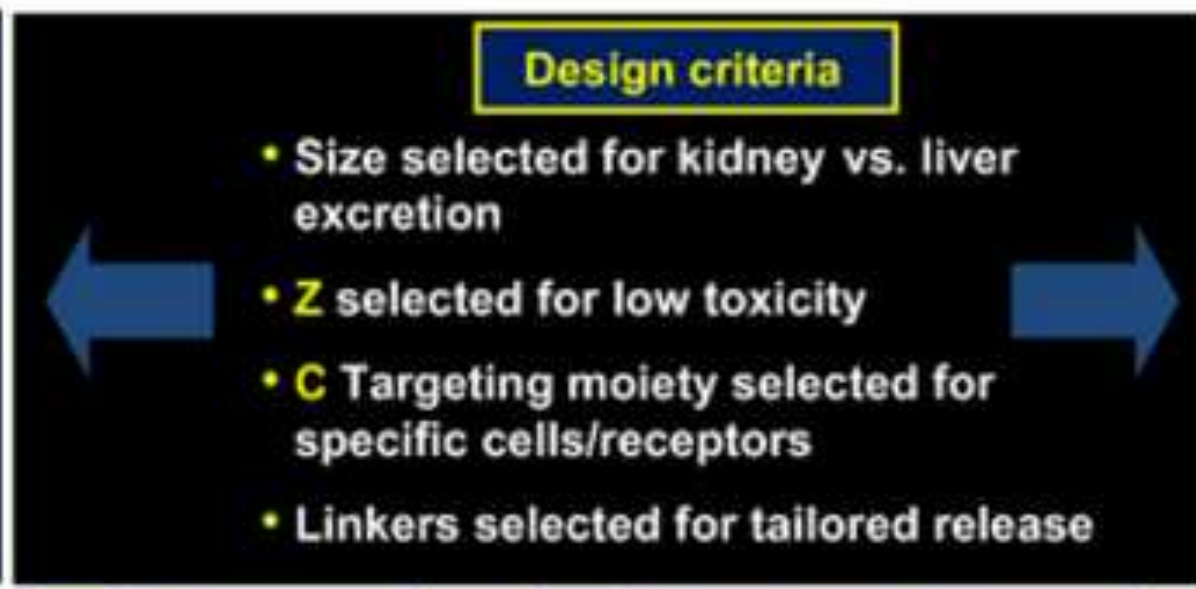

B Therapy
-Cisplatin
-Methotrexate
-Adriamycin
-SiRNA
-N-acetyl cysteine
-Steroids

C Targeting Groups -Folic acid -Carbohydrates -lgG/Fab-type antibodies -VEGF -ACPP z

z

z

G8

G9
G7

8.8

512

(Z) Biocompatible

-Carboxylate -Hydroxyl -Pyrrolidone -Acetamide -PEG

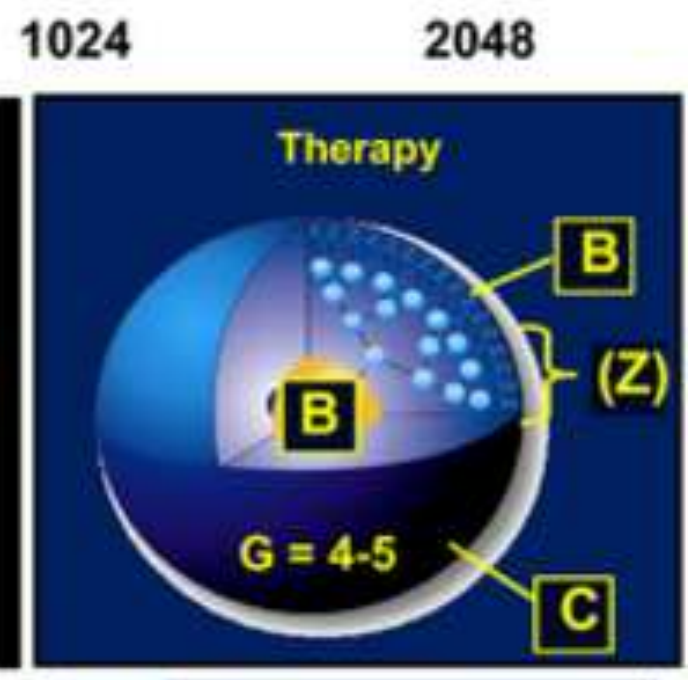

\section{$\begin{array}{ll}9.8 & 11.4\end{array}$}



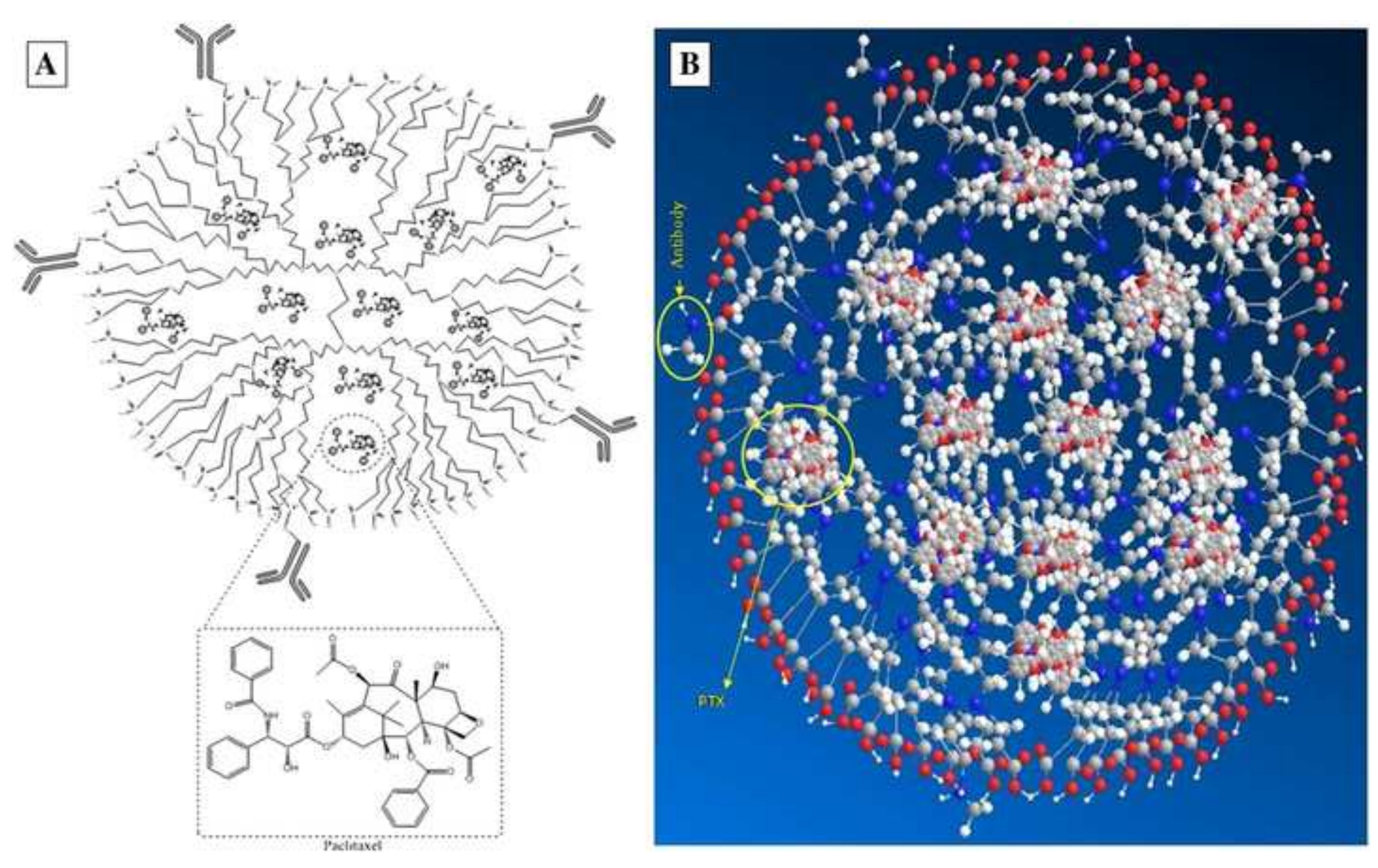
A

$\mathrm{COOH}-G G G-\mathrm{NH}_{2} \underset{\mathrm{pH} 5.5}{\stackrel{\mathrm{NHS} / \mathrm{EDC}}{\longrightarrow}} \mathrm{NHS-GGG- \textrm {NH } _ { 2 }} \stackrel{\mathrm{G} 4.0}{\longrightarrow}$

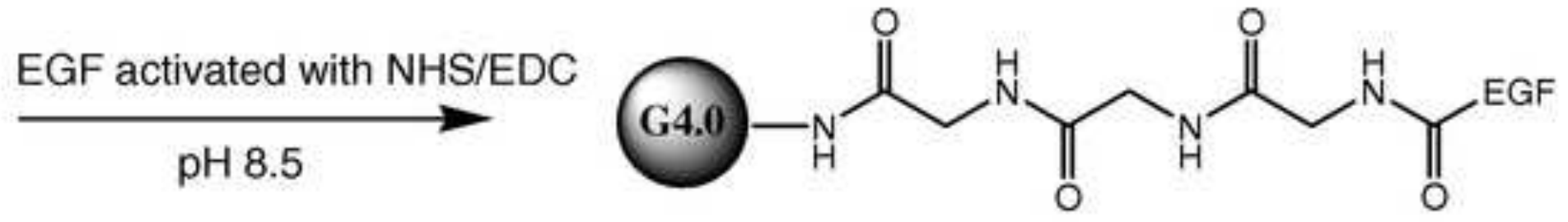

B
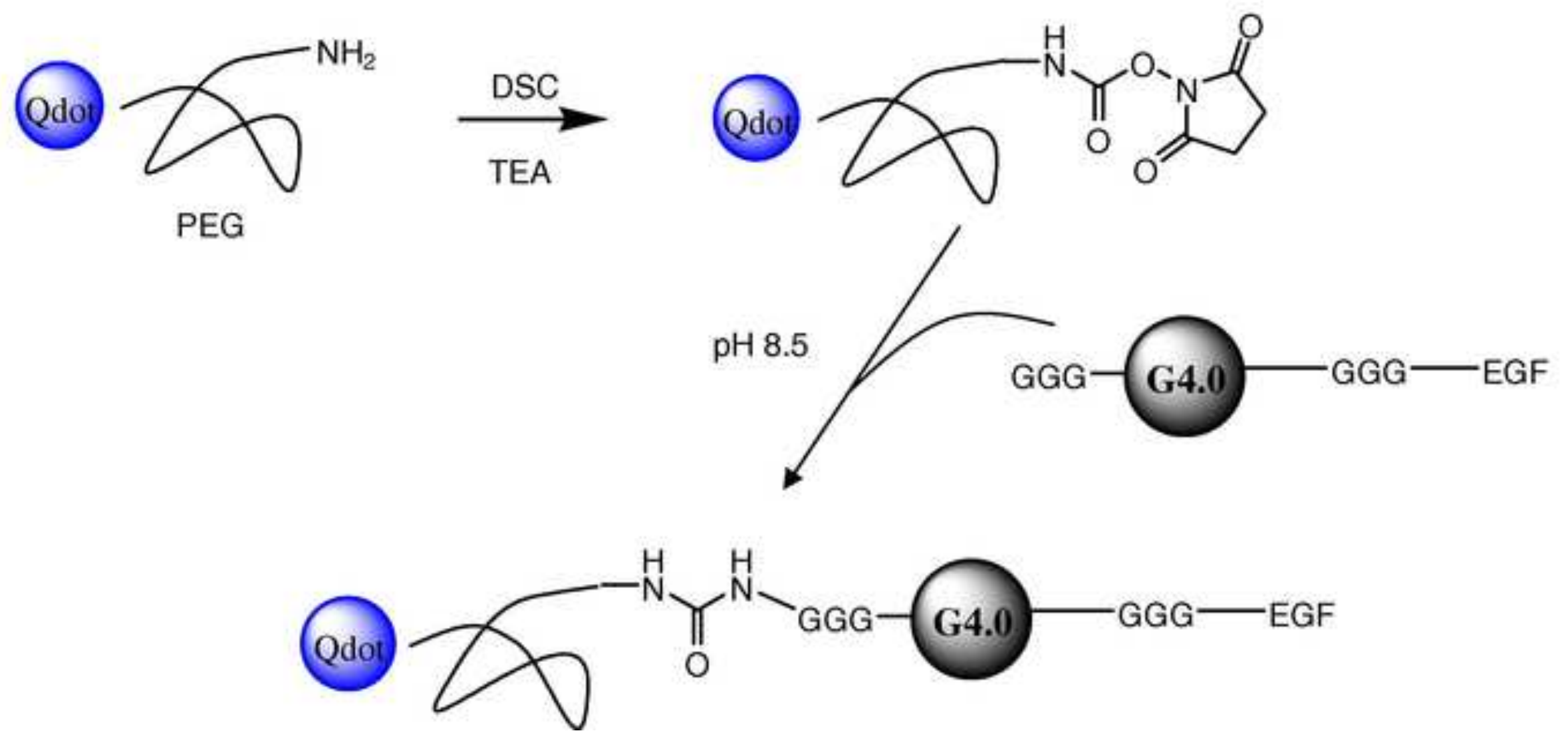
a

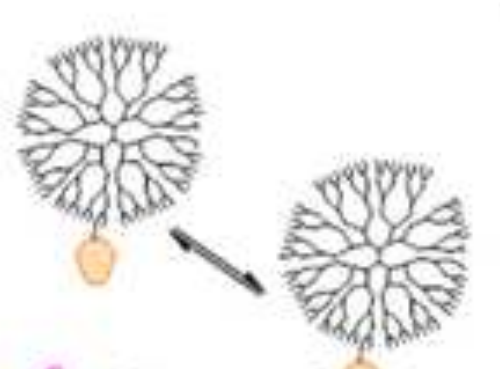

b.

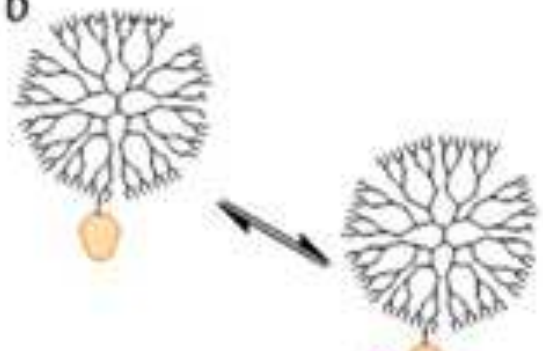

pis

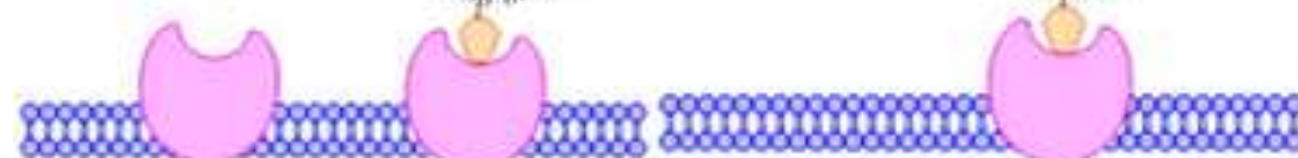
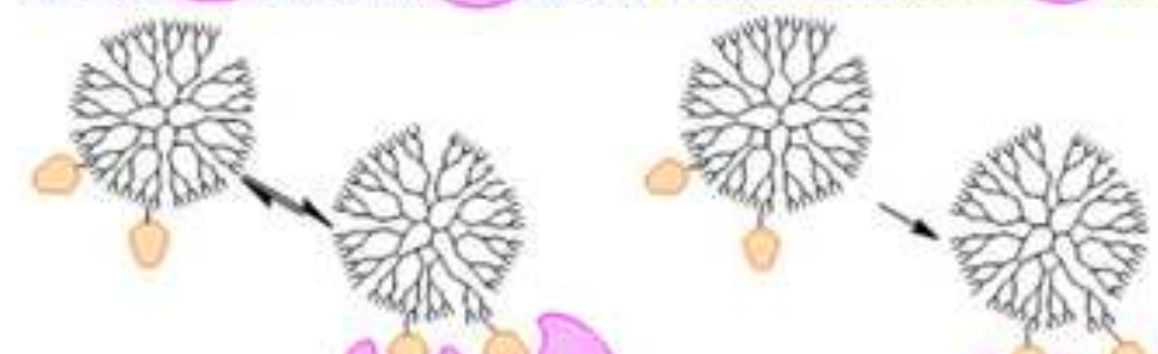

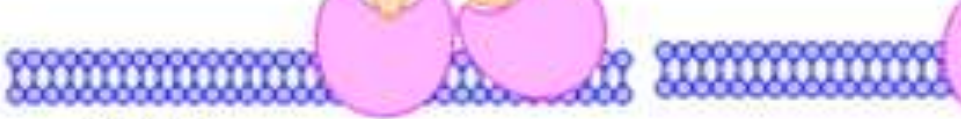

\$6. 500000

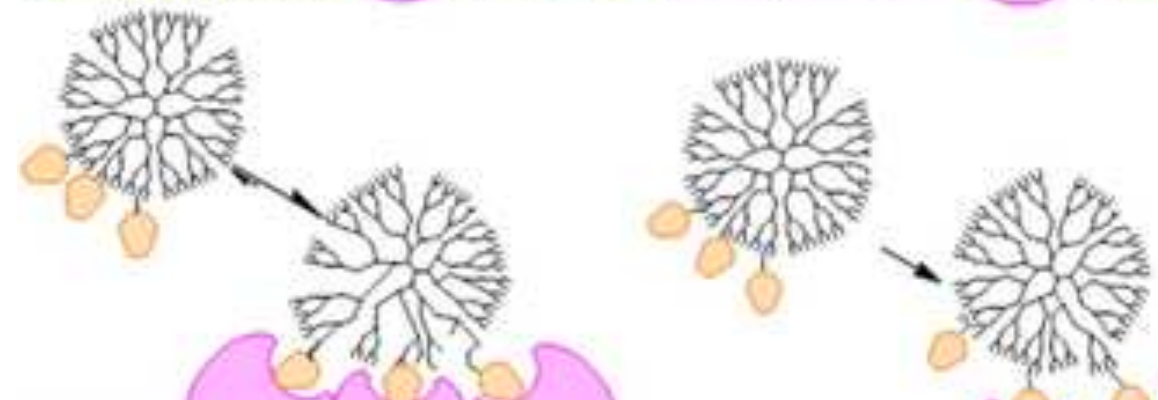

$\$ 000000000000000006$. Sobonatio

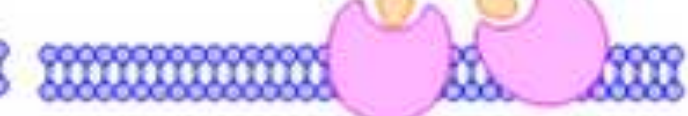

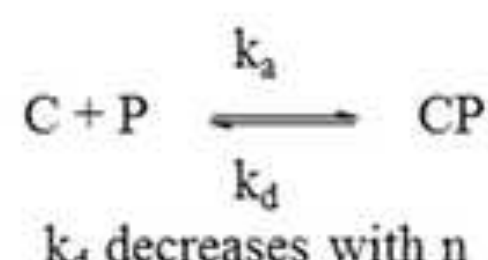

$$
\mathrm{C}+\mathrm{P} \underset{\mathrm{k}_{\mathrm{d}}=0 \text { when } \mathrm{n} \geq 2}{\stackrel{\mathrm{k}_{\mathrm{a}}}{\mathrm{w}_{\mathrm{w}}}} \mathrm{CP}
$$

c

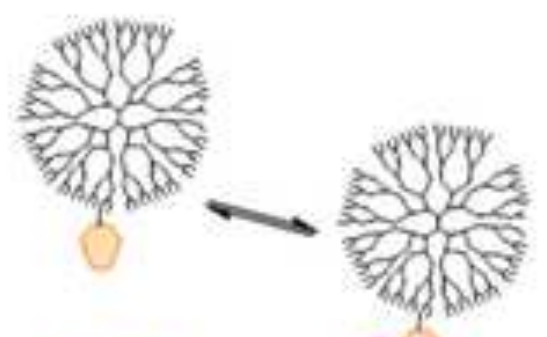

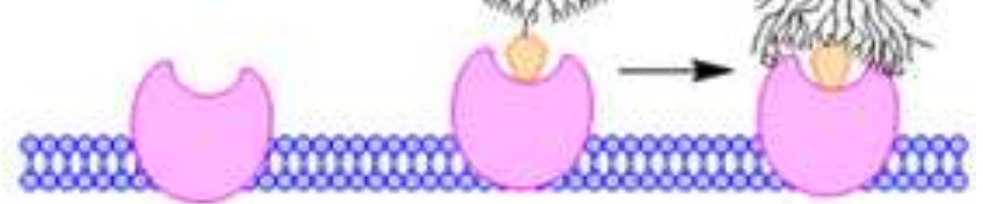

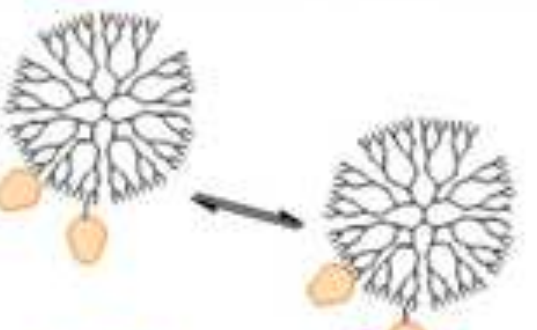

s000000

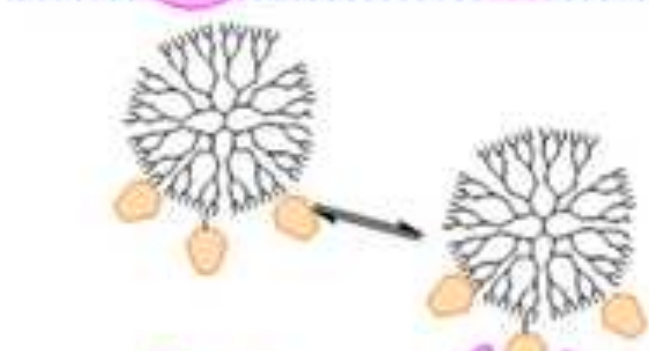

8000000 \$000000000

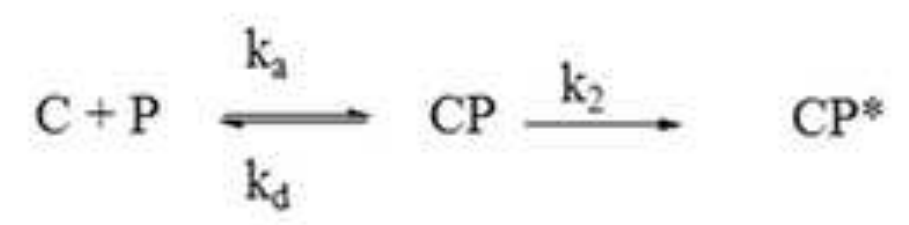




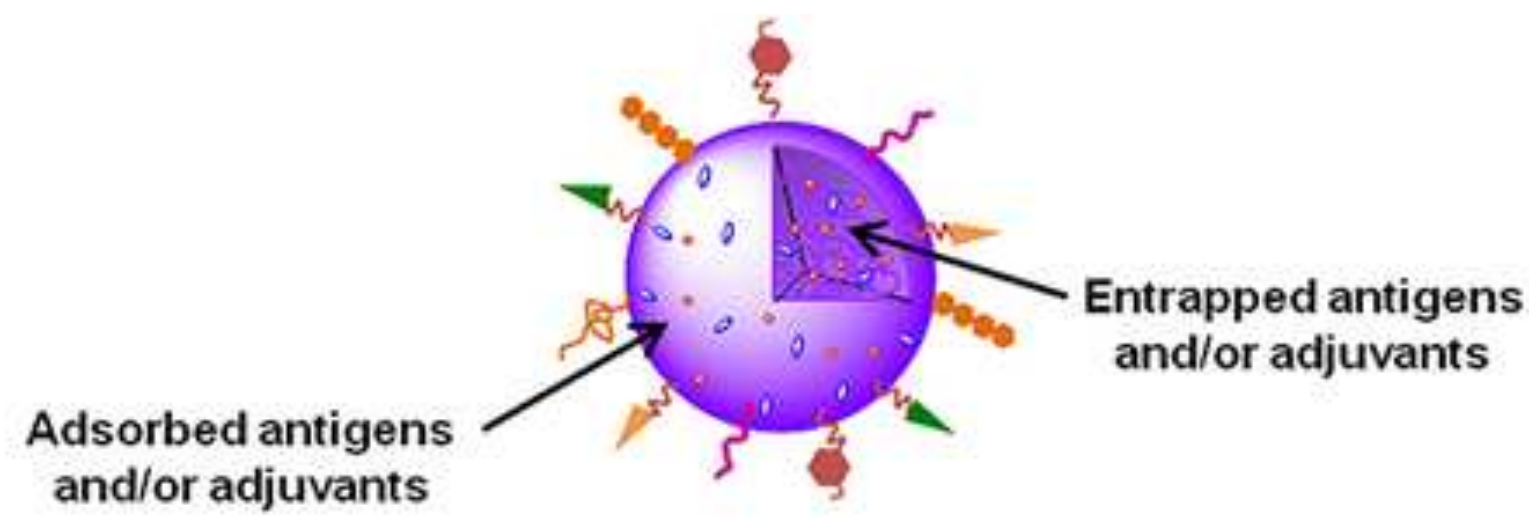

B

Immature DC (iDC)

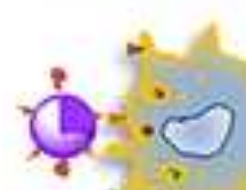

$$
\text { C) }
$$

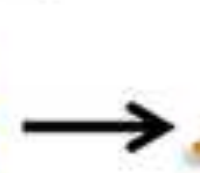

Mature DC (mDC)

Naìve T cells Cytotoxic T cells (CTLs)

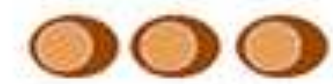

Memory T Cells
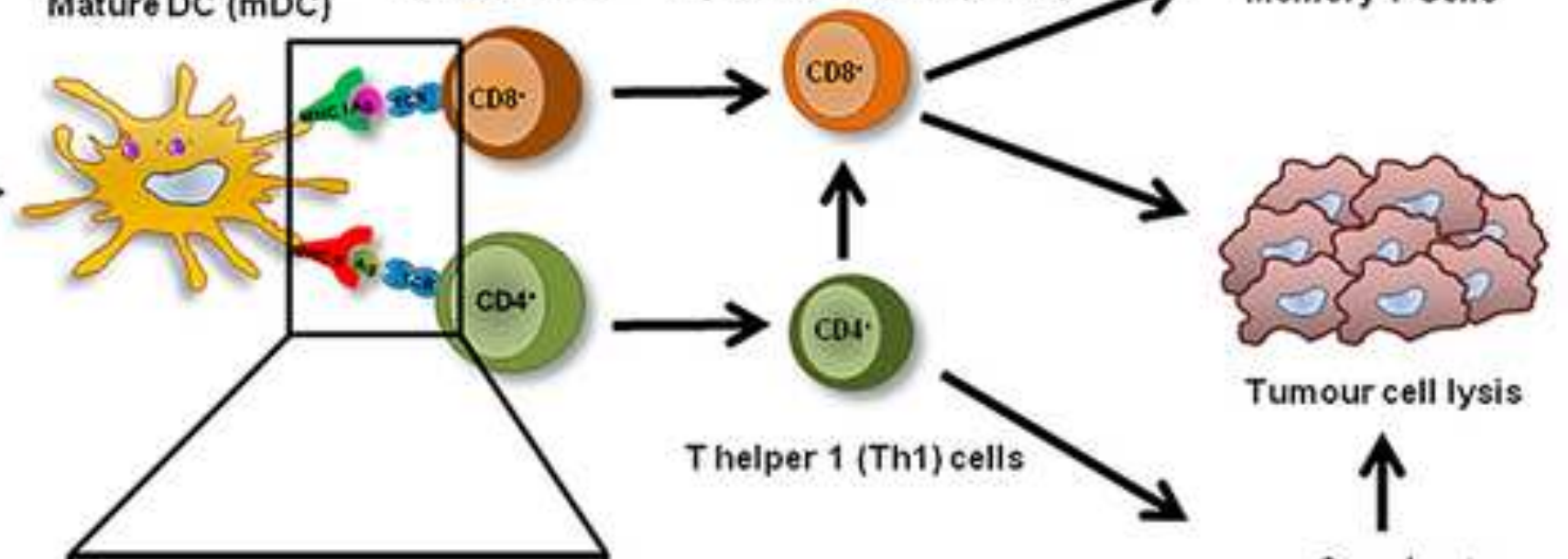

Tumour cell lysis

Major histocompatibility complex (MHC) class I

Major histocompatibility complex (MHC) class II

Antigen
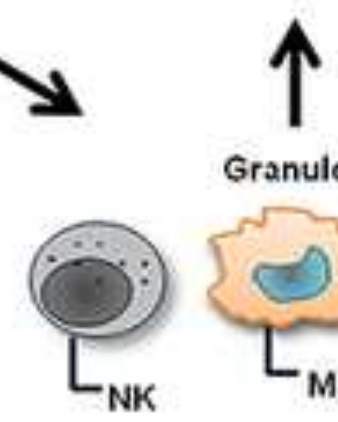

Granulocytes

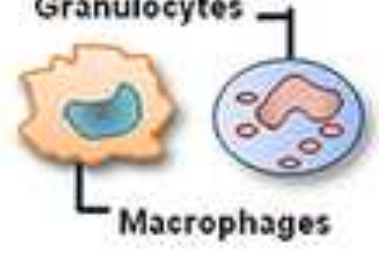

T cell receptor (TCR) 


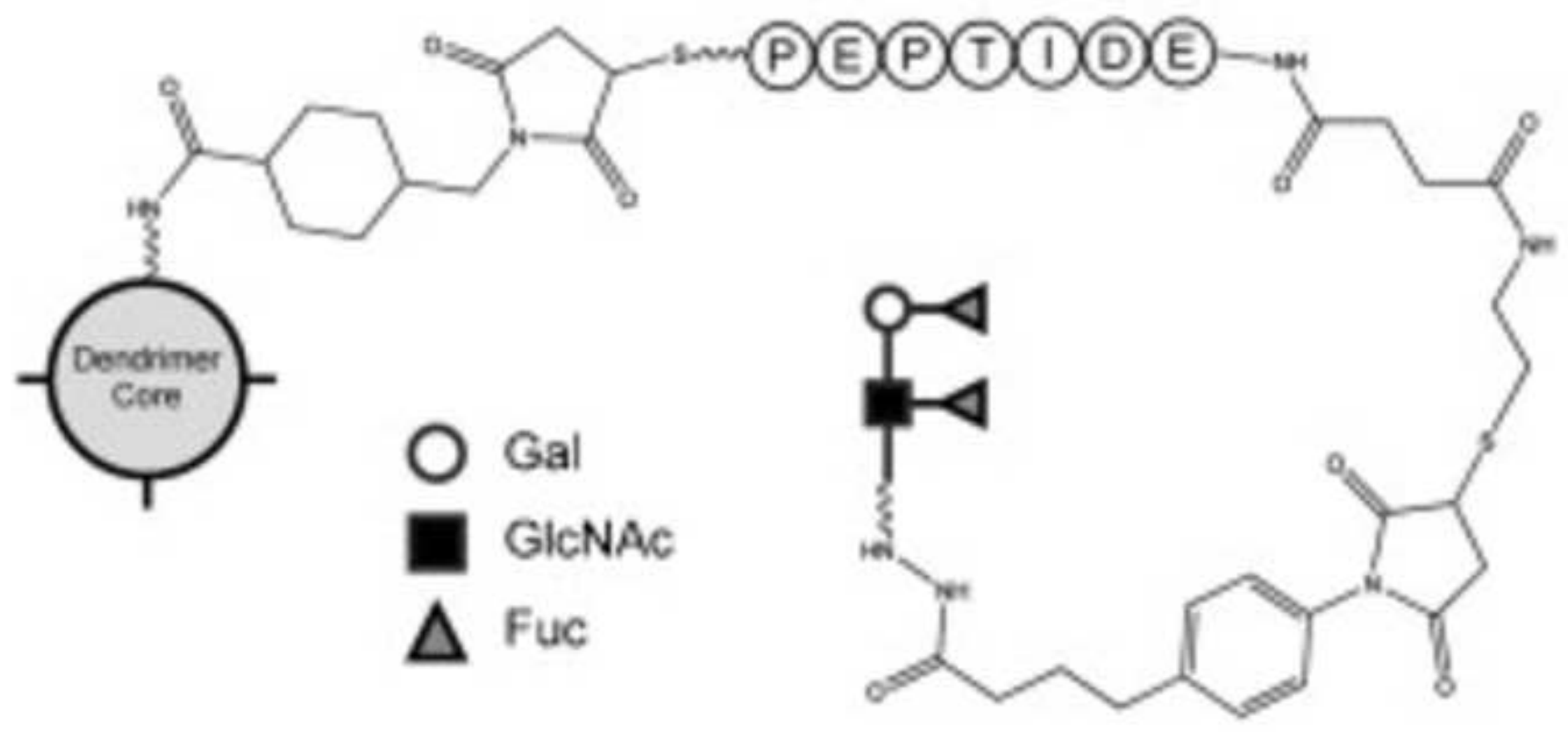

O Gal

- GicNAC

$\triangle$ Fuc 
e.g., $T$ cells, monocytes/macrophages, dendritic cells

Autologous immune cells
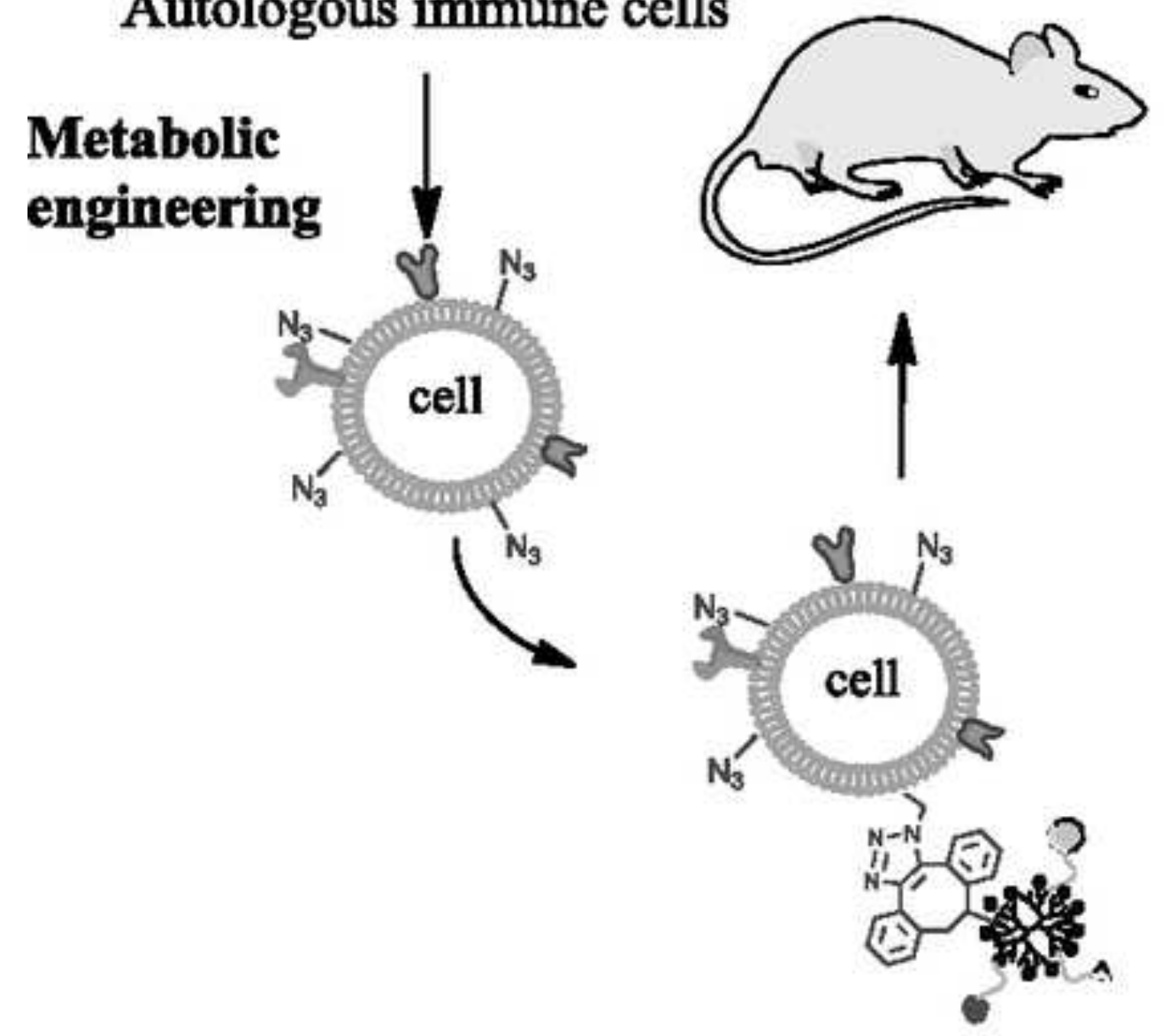

Clickable dendrimers

$\mathrm{R}=$ 政
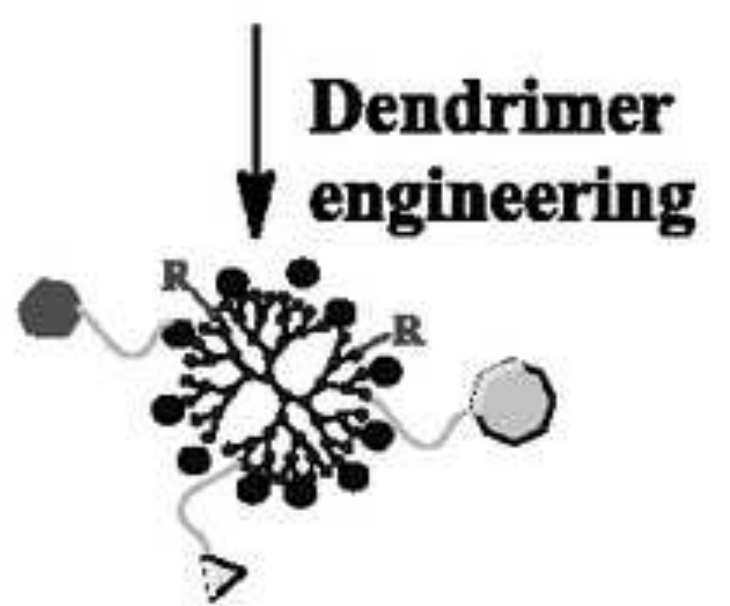

Moieties on the dendrimer -drugs -imaging probes -ligands -nucleotides -linear polymers -cell anchoring groups (e.g., strained alkyne) 


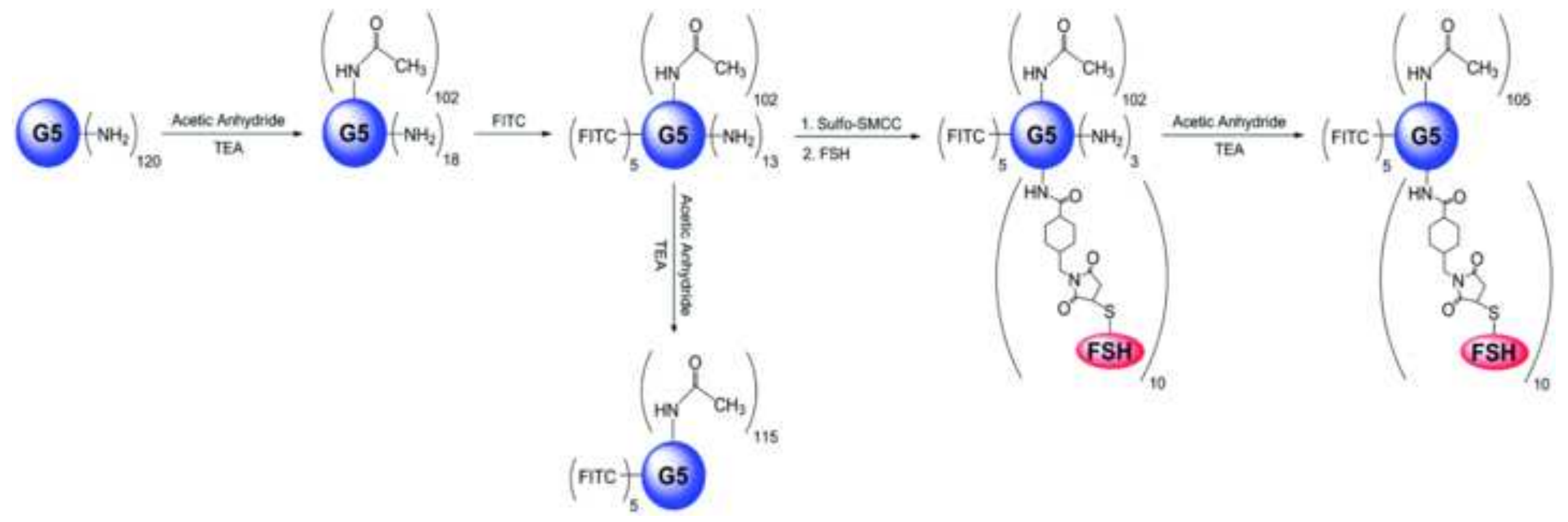




\section{JOHN WILEY AND SONS LICENSE TERMS AND CONDITIONS}

Nov 18, 2015

This Agreement between Hu Yang ("You") and John Wiley and Sons ("John Wiley and Sons") consists of your license details and the terms and conditions provided by John Wiley and Sons and Copyright Clearance Center.

License Number

License date

Licensed Content Publisher

Licensed Content Publication

Licensed Content Title

Licensed Content Author

Licensed Content Date

Pages

Type of Use

Requestor type

Is the reuse sponsored by or associated with a pharmaceutical or medical products company?

Format

Portion

Number of figures/tables

Original Wiley figure/table number(s)

Will you be translating?

Title of new article

Publication the new article is in

Publisher of new article None

Author of new article

Expected publication date of new article

Estimated size of new article (pages)

Requestor Location

Billing Type

Billing Address

Total

Terms and Conditions
3752001254410

Nov 18, 2015

John Wiley and Sons

Journal of Internal Medicine

Emerging concepts in dendrimer-based nanomedicine: from design principles to clinical applications

R. M. Kannan,E. Nance,S. Kannan,D. A. Tomalia

Jul 31, 2014

39

Journal/Magazine

University/Academic

no

Print and electronic

Figure/table

1

Figure 10

No

Targeted nanosystems: Advances in targeted dendrimers for cancer therapy

Nanomedicine: Nanotechnology, Biology, and Medicine

Elsevier

Hu Yang

Jan 2016

10

Hu Yang

401 West Main Street, Room E2242

Department of Biomedical Engineering, VCU

VCU

Richmond, VA 23284

United States

Attn: Hu Yang

Invoice

Hu Yang

401 West Main Street, Room E2242

Department of Biomedical Engineering

Virginia Commonwealth University, PO Box

Richmond, VA 23284

United States

Attn: Hu Yang

0.00 USD 


\section{TERMS AND CONDITIONS}

This copyrighted material is owned by or exclusively licensed to John Wiley \& Sons, Inc. or one of its group companies (each a"Wiley Company") or handled on behalf of a society with which a Wiley Company has exclusive publishing rights in relation to a particular work (collectively "WILEY"). By clicking "accept" in connection with completing this licensing transaction, you agree that the following terms and conditions apply to this transaction (along with the billing and payment terms and conditions established by the Copyright Clearance Center Inc., ("CCC's Billing and Payment terms and conditions"), at the time that you opened your RightsLink account (these are available at any time at http://myaccount.copyright.com).

\section{Terms and Conditions}

- The materials you have requested permission to reproduce or reuse (the "Wiley Materials") are protected by copyright.

- You are hereby granted a personal, non-exclusive, non-sub licensable (on a stand-alone basis), non-transferable, worldwide, limited license to reproduce the Wiley Materials for the purpose specified in the licensing process. This license, and any CONTENT (PDF or image file) purchased as part of your order, is for a one-time use only and limited to any maximum distribution number specified in the license. The first instance of republication or reuse granted by this license must be completed within two years of the date of the grant of this license (although copies prepared before the end date may be distributed thereafter). The Wiley Materials shall not be used in any other manner or for any other purpose, beyond what is granted in the license. Permission is granted subject to an appropriate acknowledgement given to the author, title of the material/book/journal and the publisher. You shall also duplicate the copyright notice that appears in the Wiley publication in your use of the Wiley Material. Permission is also granted on the understanding that nowhere in the text is a previously published source acknowledged for all or part of this Wiley Material. Any third party content is expressly excluded from this permission.

- With respect to the Wiley Materials, all rights are reserved. Except as expressly granted by the terms of the license, no part of the Wiley Materials may be copied, modified, adapted (except for minor reformatting required by the new Publication), translated, reproduced, transferred or distributed, in any form or by any means, and no derivative works may be made based on the Wiley Materials without the prior permission of the respective copyright owner.For STM Signatory Publishers clearing permission under the terms of the STM Permissions Guidelines only, the terms of the license are extended to include subsequent editions and for editions in other languages, provided such editions are for the work as a whole in situ and does not involve the separate exploitation of the permitted figures or extracts, You may not alter, remove or suppress in any manner any copyright, trademark or other notices displayed by the Wiley Materials. You may not license, rent, sell, loan, lease, pledge, offer as security, transfer or assign the Wiley Materials on a stand-alone basis, or any of the rights granted to you hereunder to any other person.

- The Wiley Materials and all of the intellectual property rights therein shall at all times remain the exclusive property of John Wiley \& Sons Inc, the Wiley Companies, or their respective licensors, and your interest therein is only that of having possession of and the right to reproduce the Wiley Materials pursuant to Section 2 herein during the continuance of this Agreement. You agree that you own no right, title or interest in or to the Wiley Materials or any of the intellectual property rights therein. You shall have no rights hereunder other than the license as provided for above in Section 2. No right, license or interest to any trademark, trade name, service mark or other branding ("Marks") of WILEY or its licensors is granted hereunder, and you agree that you shall not assert any such right, license or interest with respect thereto

- NEITHER WILEY NOR ITS LICENSORS MAKES ANY WARRANTY OR REPRESENTATION OF ANY KIND TO YOU OR ANY THIRD PARTY, EXPRESS, IMPLIED OR STATUTORY, WITH RESPECT TO THE MATERIALS OR THE ACCURACY OF ANY INFORMATION CONTAINED IN THE MATERIALS, INCLUDING, WITHOUT LIMITATION, ANY IMPLIED WARRANTY OF MERCHANTABILITY, ACCURACY, SATISFACTORY QUALITY, FITNESS FOR A PARTICULAR PURPOSE, USABILITY, INTEGRATION OR NON-INFRINGEMENT AND ALL SUCH WARRANTIES ARE HEREBY EXCLUDED BY WILEY AND ITS LICENSORS AND WAIVED BY YOU.

- WILEY shall have the right to terminate this Agreement immediately upon breach of this Agreement by you.

- You shall indemnify, defend and hold harmless WILEY, its Licensors and their respective directors, officers, agents and employees, from and against any actual or threatened claims, demands, causes of action or proceedings arising from any breach of this Agreement by you.

- IN NO EVENT SHALL WILEY OR ITS LICENSORS BE LIABLE TO YOU OR ANY OTHER PARTY OR ANY OTHER PERSON OR ENTITY FOR ANY SPECIAL, CONSEQUENTIAL, INCIDENTAL, INDIRECT, EXEMPLARY OR PUNITIVE DAMAGES, HOWEVER CAUSED, ARISING OUT OF OR IN CONNECTION WITH THE DOWNLOADING, 
PROVISIONING, VIEWING OR USE OF THE MATERIALS REGARDLESS OF THE FORM OF ACTION, WHETHER FOR BREACH OF CONTRACT, BREACH OF WARRANTY, TORT, NEGLIGENCE, INFRINGEMENT OR OTHERWISE (INCLUDING, WITHOUT LIMITATION, DAMAGES BASED ON LOSS OF PROFITS, DATA, FILES, USE, BUSINESS OPPORTUNITY OR CLAIMS OF THIRD PARTIES), AND WHETHER OR NOT THE PARTY HAS BEEN ADVISED OF THE POSSIBILITY OF SUCH DAMAGES. THIS LIMITATION SHALL APPLY NOTWITHSTANDING ANY FAILURE OF ESSENTIAL PURPOSE OF ANY LIMITED REMEDY PROVIDED HEREIN.

- Should any provision of this Agreement be held by a court of competent jurisdiction to be illegal, invalid, or unenforceable, that provision shall be deemed amended to achieve as nearly as possible the same economic effect as the original provision, and the legality, validity and enforceability of the remaining provisions of this Agreement shall not be affected or impaired thereby.

- The failure of either party to enforce any term or condition of this Agreement shall not constitute a waiver of either party's right to enforce each and every term and condition of this Agreement. No breach under this agreement shall be deemed waived or excused by either party unless such waiver or consent is in writing signed by the party granting such waiver or consent. The waiver by or consent of a party to a breach of any provision of this Agreement shall not operate or be construed as a waiver of or consent to any other or subsequent breach by such other party.

- This Agreement may not be assigned (including by operation of law or otherwise) by you without WILEY's prior written consent.

- Any fee required for this permission shall be non-refundable after thirty (30) days from receipt by the CCC.

- These terms and conditions together with CCC's Billing and Payment terms and conditions (which are incorporated herein) form the entire agreement between you and WILEY concerning this licensing transaction and (in the absence of fraud) supersedes all prior agreements and representations of the parties, oral or written. This Agreement may not be amended except in writing signed by both parties. This Agreement shall be binding upon and inure to the benefit of the parties' successors, legal representatives, and authorized assigns.

- In the event of any conflict between your obligations established by these terms and conditions and those established by CCC's Billing and Payment terms and conditions, these terms and conditions shall prevail.

- WILEY expressly reserves all rights not specifically granted in the combination of (i) the license details provided by you and accepted in the course of this licensing transaction, (ii) these terms and conditions and (iii) CCC's Billing and Payment terms and conditions.

- This Agreement will be void if the Type of Use, Format, Circulation, or Requestor Type was misrepresented during the licensing process.

- This Agreement shall be governed by and construed in accordance with the laws of the State of New York, USA, without regards to such state's conflict of law rules. Any legal action, suit or proceeding arising out of or relating to these Terms and Conditions or the breach thereof shall be instituted in a court of competent jurisdiction in New York County in the State of New York in the United States of America and each party hereby consents and submits to the personal jurisdiction of such court, waives any objection to venue in such court and consents to service of process by registered or certified mail, return receipt requested, at the last known address of such party.

\section{WILEY OPEN ACCESS TERMS AND CONDITIONS}

Wiley Publishes Open Access Articles in fully Open Access Journals and in Subscription journals offering Online Open. Although most of the fully Open Access journals publish open access articles under the terms of the Creative Commons Attribution (CC BY) License only, the subscription journals and a few of the Open Access Journals offer a choice of Creative Commons Licenses. The license type is clearly identified on the article.

The Creative Commons Attribution License

The Creative Commons Attribution License (CC-BY) allows users to copy, distribute and transmit an article, adapt the article and make commercial use of the article. The CC-BY license permits commercial and non-

Creative Commons Attribution Non-Commercial License

The Creative Commons Attribution Non-Commercial (CC-BY-NC)License permits use, distribution and reproduction in any medium, provided the original work is properly cited and is not used for commercial purposes.(see below) 


\section{Creative Commons Attribution-Non-Commercial-NoDerivs License}

The Creative Commons Attribution Non-Commercial-NoDerivs License (CC-BY-NC-ND) permits use, distribution and reproduction in any medium, provided the original work is properly cited, is not used for commercial purposes and no modifications or adaptations are made. (see below)

Use by commercial "for-profit" organizations

Use of Wiley Open Access articles for commercial, promotional, or marketing purposes requires further explicit permission from Wiley and will be subject to a fee.

Further details can be found on Wiley Online Library http://olabout.wiley.com/WileyCDA/Section/id-410895.html

Other Terms and Conditions:

v1.10 Last updated September 2015

Questions? customercare@copyright.com or +1-855-239-3415 (toll free in the US) or +1-978-646-2777. 


\section{ELSEVIER LICENSE TERMS AND CONDITIONS}

Nov 18, 2015

This is an Agreement between Hu Yang ("You") and Elsevier ("Elsevier"). It consists of your order details, the terms and conditions provided by Elsevier, and the payment terms and conditions.

All payments must be made in full to CCC. For payment instructions, please see information listed at the bottom of this form.

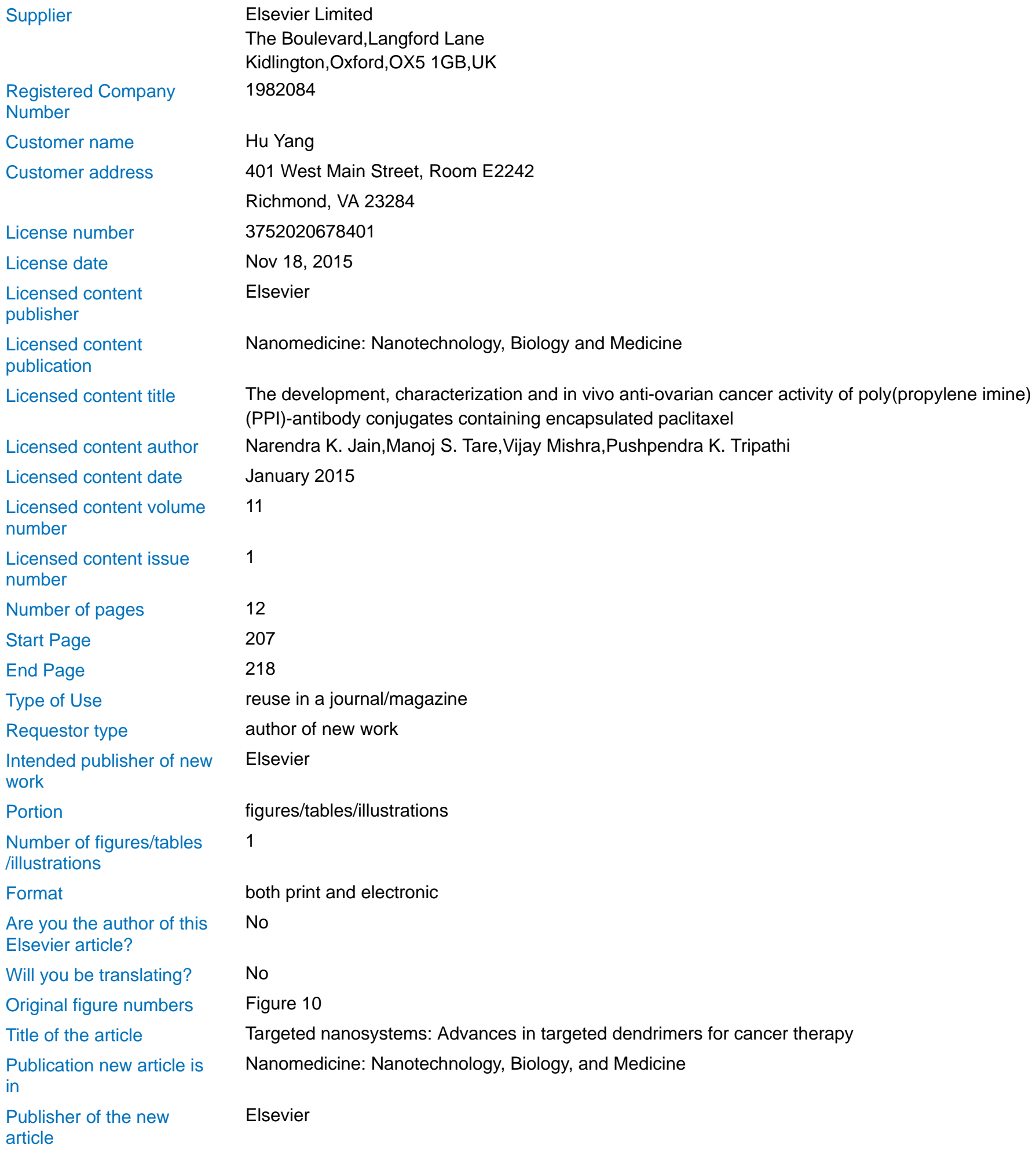

Licensed content issue $\quad 1$

Number of pages $\quad 12$

End Page 218

Hu Yang

401 West Main Street, Room E2242

Richmond, VA 23284

3752020678401

Nov 18, 2015

Elsevier

Nanomedicine: Nanotechnology, Biology and Medicine

The development, characterization and in vivo anti-ovarian cancer activity of poly(propylene imine) (PPI)-antibody conjugates containing encapsulated paclitaxel

Narendra K. Jain,Manoj S. Tare,Vijay Mishra,Pushpendra K. Tripathi

January 2015

11

reuse in a journal/magazine

author of new work

Elsevier

figures/tables/illustrations

1

both print and electronic

No

No

Figure 10

Targeted nanosystems: Advances in targeted dendrimers for cancer therapy

Nanomedicine: Nanotechnology, Biology, and Medicine

Elsevier 


Author of new article
Expected publication date
Estimated size of new
article (number of pages)
Elsevier VAT number
Price
VAT/Local Sales Tax

Total

Terms and Conditions

\author{
Hu Yang \\ Jan 2016 \\ 10 \\ GB 494627212 \\ 0.00 USD \\ 0.00 USD / 0.00 GBP
}

\subsection{USD}

\section{INTRODUCTION}

1. The publisher for this copyrighted material is Elsevier. By clicking "accept" in connection with completing this licensing transaction, you agree that the following terms and conditions apply to this transaction (along with the Billing and Payment terms and conditions established by Copyright Clearance Center, Inc. ("CCC"), at the time that you opened your Rightslink account and that are available at any time at http://myaccount.copyright.com).

\section{GENERAL TERMS}

2. Elsevier hereby grants you permission to reproduce the aforementioned material subject to the terms and conditions indicated. 3. Acknowledgement: If any part of the material to be used (for example, figures) has appeared in our publication with credit or acknowledgement to another source, permission must also be sought from that source. If such permission is not obtained then that material may not be included in your publication/copies. Suitable acknowledgement to the source must be made, either as a footnote or in a reference list at the end of your publication, as follows:

"Reprinted from Publication title, Vol /edition number, Author(s), Title of article / title of chapter, Pages No., Copyright (Year), with permission from Elsevier [OR APPLICABLE SOCIETY COPYRIGHT OWNER]." Also Lancet special credit - "Reprinted from The Lancet, Vol. number, Author(s), Title of article, Pages No., Copyright (Year), with permission from Elsevier."

4. Reproduction of this material is confined to the purpose and/or media for which permission is hereby given.

5. Altering/Modifying Material: Not Permitted. However figures and illustrations may be altered/adapted minimally to serve your work. Any other abbreviations, additions, deletions and/or any other alterations shall be made only with prior written authorization of Elsevier Ltd. (Please contact Elsevier at permissions@elsevier.com)

6. If the permission fee for the requested use of our material is waived in this instance, please be advised that your future requests for Elsevier materials may attract a fee.

7. Reservation of Rights: Publisher reserves all rights not specifically granted in the combination of (i) the license details provided by you and accepted in the course of this licensing transaction, (ii) these terms and conditions and (iii) CCC's Billing and Payment terms and conditions.

8. License Contingent Upon Payment: While you may exercise the rights licensed immediately upon issuance of the license at the end of the licensing process for the transaction, provided that you have disclosed complete and accurate details of your proposed use, no license is finally effective unless and until full payment is received from you (either by publisher or by CCC) as provided in CCC's Billing and Payment terms and conditions. If full payment is not received on a timely basis, then any license preliminarily granted shall be deemed automatically revoked and shall be void as if never granted. Further, in the event that you breach any of these terms and conditions or any of CCC's Billing and Payment terms and conditions, the license is automatically revoked and shall be void as if never granted. Use of materials as described in a revoked license, as well as any use of the materials beyond the scope of an unrevoked license, may constitute copyright infringement and publisher reserves the right to take any and all action to protect its copyright in the materials.

9. Warranties: Publisher makes no representations or warranties with respect to the licensed material.

10. Indemnity: You hereby indemnify and agree to hold harmless publisher and CCC, and their respective officers, directors, employees and agents, from and against any and all claims arising out of your use of the licensed material other than as specifically authorized pursuant to this license.

11. No Transfer of License: This license is personal to you and may not be sublicensed, assigned, or transferred by you to any other person without publisher's written permission.

12. No Amendment Except in Writing: This license may not be amended except in a writing signed by both parties (or, in the case of publisher, by CCC on publisher's behalf).

13. Objection to Contrary Terms: Publisher hereby objects to any terms contained in any purchase order, acknowledgment, check endorsement or other writing prepared by you, which terms are inconsistent with these terms and conditions or CCC's Billing and Payment terms and conditions. These terms and conditions, together with CCC's Billing and Payment terms and conditions (which are incorporated herein), comprise the entire agreement between you and publisher (and CCC) concerning this licensing transaction. In the event of any conflict between your obligations established by these terms and conditions and those established by CCC's Billing and Payment terms and conditions, these terms and conditions shall control.

14. Revocation: Elsevier or Copyright Clearance Center may deny the permissions described in this License at their sole discretion, for any reason or no reason, with a full refund payable to you. Notice of such denial will be made using the contact 
information provided by you. Failure to receive such notice will not alter or invalidate the denial. In no event will Elsevier or Copyright Clearance Center be responsible or liable for any costs, expenses or damage incurred by you as a result of a denial of your permission request, other than a refund of the amount(s) paid by you to Elsevier and/or Copyright Clearance Center for denied permissions.

\section{LIMITED LICENSE}

The following terms and conditions apply only to specific license types:

15. Translation: This permission is granted for non-exclusive world English rights only unless your license was granted for translation rights. If you licensed translation rights you may only translate this content into the languages you requested. A professional translator must perform all translations and reproduce the content word for word preserving the integrity of the article.

16. Posting licensed content on any Website: The following terms and conditions apply as follows: Licensing material from an Elsevier journal: All content posted to the web site must maintain the copyright information line on the bottom of each image; $A$ hyper-text must be included to the Homepage of the journal from which you are licensing at http://www.sciencedirect.com/science /journal/xxxxx or the Elsevier homepage for books at http://www.elsevier.com; Central Storage: This license does not include permission for a scanned version of the material to be stored in a central repository such as that provided by Heron/XanEdu. Licensing material from an Elsevier book: A hyper-text link must be included to the Elsevier homepage at http://www.elsevier.com . All content posted to the web site must maintain the copyright information line on the bottom of each image.

Posting licensed content on Electronic reserve: In addition to the above the following clauses are applicable: The web site must be password-protected and made available only to bona fide students registered on a relevant course. This permission is granted for 1 year only. You may obtain a new license for future website posting.

17. For journal authors: the following clauses are applicable in addition to the above:

Preprints:

A preprint is an author's own write-up of research results and analysis, it has not been peer-reviewed, nor has it had any other value added to it by a publisher (such as formatting, copyright, technical enhancement etc.).

Authors can share their preprints anywhere at any time. Preprints should not be added to or enhanced in any way in order to appear more like, or to substitute for, the final versions of articles however authors can update their preprints on arXiv or RePEc with their Accepted Author Manuscript (see below).

If accepted for publication, we encourage authors to link from the preprint to their formal publication via its DOI. Millions of researchers have access to the formal publications on ScienceDirect, and so links will help users to find, access, cite and use the best available version. Please note that Cell Press, The Lancet and some society-owned have different preprint policies. Information on these policies is available on the journal homepage.

Accepted Author Manuscripts: An accepted author manuscript is the manuscript of an article that has been accepted for publication and which typically includes author-incorporated changes suggested during submission, peer review and editor-author communications.

Authors can share their accepted author manuscript:

- immediately

viaptheir non-commercial person homepage or blog

byaupdating a preprint in arXiv or RePEc with the accepted manuscript

viaptheir research institute or institutional repository for internal institutional uses or as part of an invitation-only research collaboration work-group

directly by providing copies to their students or to research collaborators for their personal use

foroprivate scholarly sharing as part of an invitation-only work group on commercial sites with which Elsevier has an agreement

- $\quad$ after the embargo period vianon-commercial hosting platforms such as their institutional repository viapcommercial sites with which Elsevier has an agreement

In all cases accepted manuscripts should:

- $\quad$ link to the formal publication via its DOI

- $\quad$ bear a CC-BY-NC-ND license - this is easy to do

- $\quad$ if aggregated with other manuscripts, for example in a repository or other site, be shared in alignment with our hosting policy not be added to or enhanced in any way to appear more like, or to substitute for, the published journal article.

Published journal article (JPA): A published journal article (PJA) is the definitive final record of published research that appears or will appear in the journal and embodies all value-adding publishing activities including peer review co-ordination, copy-editing, formatting, (if relevant) pagination and online enrichment.

Policies for sharing publishing journal articles differ for subscription and gold open access articles: 
Subscription Articles: If you are an author, please share a link to your article rather than the full-text. Millions of researchers have access to the formal publications on ScienceDirect, and so links will help your users to find, access, cite, and use the best available version.

Theses and dissertations which contain embedded PJAs as part of the formal submission can be posted publicly by the awarding institution with DOI links back to the formal publications on ScienceDirect.

If you are affiliated with a library that subscribes to ScienceDirect you have additional private sharing rights for others' research accessed under that agreement. This includes use for classroom teaching and internal training at the institution (including use in course packs and courseware programs), and inclusion of the article for grant funding purposes.

Gold Open Access Articles: May be shared according to the author-selected end-user license and should contain a CrossMark

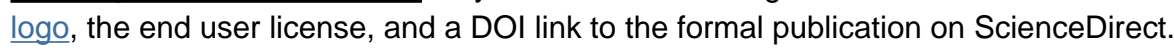

Please refer to Elsevier's posting policy for further information.

18. For book authors the following clauses are applicable in addition to the above: Authors are permitted to place a brief summary of their work online only. You are not allowed to download and post the published electronic version of your chapter, nor may you scan the printed edition to create an electronic version. Posting to a repository: Authors are permitted to post a summary of their chapter only in their institution's repository.

19. Thesis/Dissertation: If your license is for use in a thesis/dissertation your thesis may be submitted to your institution in either print or electronic form. Should your thesis be published commercially, please reapply for permission. These requirements include permission for the Library and Archives of Canada to supply single copies, on demand, of the complete thesis and include permission for Proquest/UMI to supply single copies, on demand, of the complete thesis. Should your thesis be published commercially, please reapply for permission. Theses and dissertations which contain embedded PJAs as part of the formal submission can be posted publicly by the awarding institution with DOI links back to the formal publications on ScienceDirect.

\section{Elsevier Open Access Terms and Conditions}

You can publish open access with Elsevier in hundreds of open access journals or in nearly 2000 established subscription journals that support open access publishing. Permitted third party re-use of these open access articles is defined by the author's choice of Creative Commons user license. See our open access license policy for more information.

Terms \& Conditions applicable to all Open Access articles published with Elsevier:

Any reuse of the article must not represent the author as endorsing the adaptation of the article nor should the article be modified in such a way as to damage the author's honour or reputation. If any changes have been made, such changes must be clearly indicated.

The author(s) must be appropriately credited and we ask that you include the end user license and a DOI link to the formal publication on ScienceDirect.

If any part of the material to be used (for example, figures) has appeared in our publication with credit or acknowledgement to another source it is the responsibility of the user to ensure their reuse complies with the terms and conditions determined by the rights holder.

Additional Terms \& Conditions applicable to each Creative Commons user license:

CC BY: The CC-BY license allows users to copy, to create extracts, abstracts and new works from the Article, to alter and revise the Article and to make commercial use of the Article (including reuse and/or resale of the Article by commercial entities), provided the user gives appropriate credit (with a link to the formal publication through the relevant DOI), provides a link to the license, indicates if changes were made and the licensor is not represented as endorsing the use made of the work. The full details of the license are available at http://creativecommons.org/licenses/by/4.0.

CC BY NC SA: The CC BY-NC-SA license allows users to copy, to create extracts, abstracts and new works from the Article, to alter and revise the Article, provided this is not done for commercial purposes, and that the user gives appropriate credit (with a link to the formal publication through the relevant DOI), provides a link to the license, indicates if changes were made and the licensor is not represented as endorsing the use made of the work. Further, any new works must be made available on the same conditions. The full details of the license are available at http://creativecommons.org/licenses/by-nc-sa/4.0.

CC BY NC ND: The CC BY-NC-ND license allows users to copy and distribute the Article, provided this is not done for commercial purposes and further does not permit distribution of the Article if it is changed or edited in any way, and provided the user gives appropriate credit (with a link to the formal publication through the relevant DOI), provides a link to the license, and that the licensor is not represented as endorsing the use made of the work. The full details of the license are available at http://creativecommons.org/licenses/by-nc-nd/4.0. Any commercial reuse of Open Access articles published with a CC BY NC SA or CC BY NC ND license requires permission from Elsevier and will be subject to a fee.

Commercial reuse includes:

- $\quad$ Associating advertising with the full text of the Article

- $\quad$ Charging fees for document delivery or access

- Article aggregation

- $\quad$ Systematic distribution via e-mail lists or share buttons 
Posting or linking by commercial companies for use by customers of those companies.

20. Other Conditions:

v1.8

Questions? customercare@copyright.com or +1-855-239-3415 (toll free in the US) or +1-978-646-2777. 


\section{ELSEVIER LICENSE TERMS AND CONDITIONS}

Nov 18, 2015

This is an Agreement between Hu Yang ("You") and Elsevier ("Elsevier"). It consists of your order details, the terms and conditions provided by Elsevier, and the payment terms and conditions.

All payments must be made in full to CCC. For payment instructions, please see information listed at the bottom of this form.

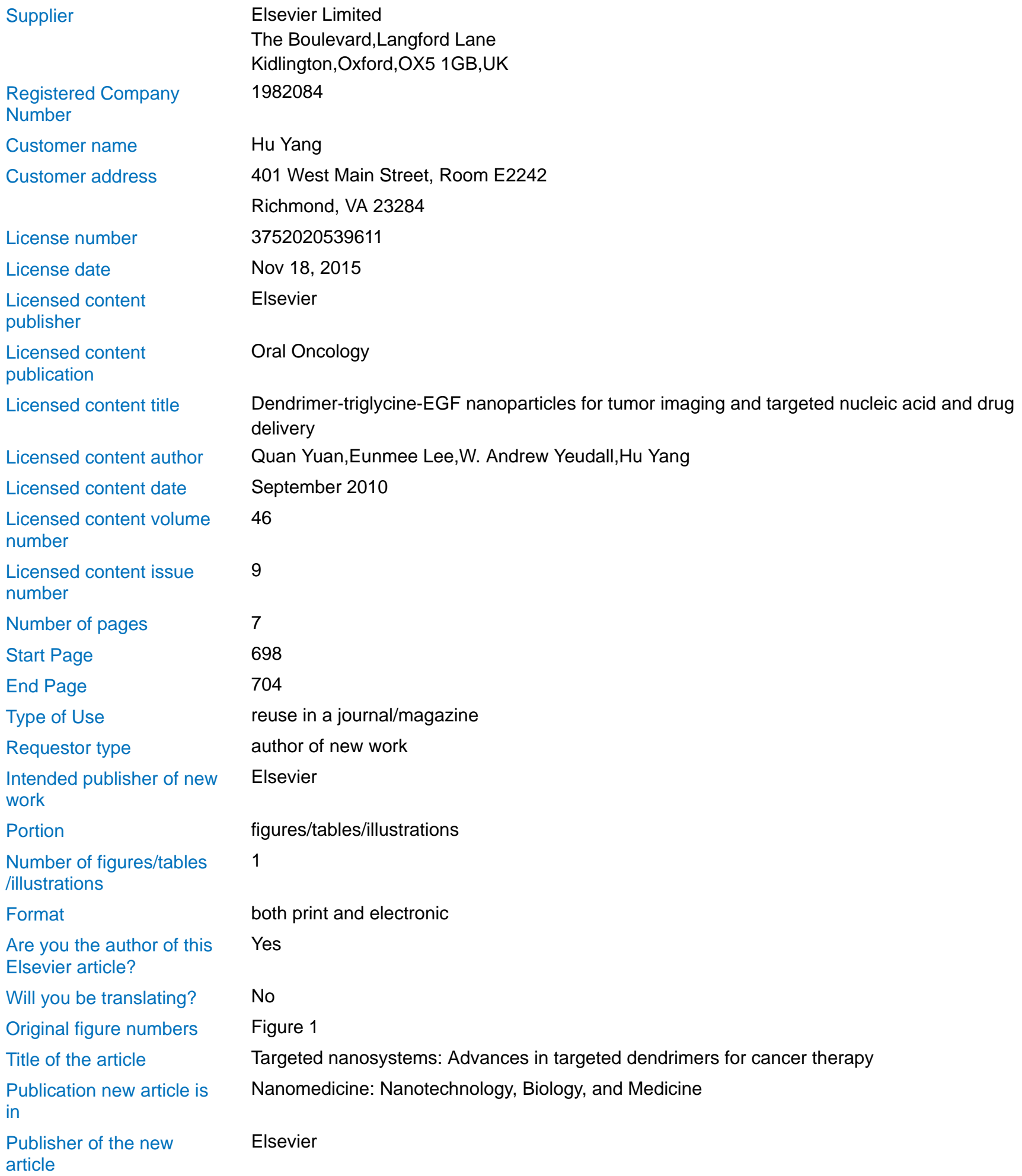

Licensed content issue $\quad 9$

End Page 704

Hu Yang

401 West Main Street, Room E2242

Richmond, VA 23284

3752020539611

Nov 18, 2015

Elsevier

Oral Oncology

Dendrimer-triglycine-EGF nanoparticles for tumor imaging and targeted nucleic acid and drug delivery

Quan Yuan,Eunmee Lee,W. Andrew Yeudall,Hu Yang

September 2010

46

7

reuse in a journal/magazine

author of new work

Elsevier

figures/tables/illustrations

1

both print and electronic

Yes

No

Figure 1

Targeted nanosystems: Advances in targeted dendrimers for cancer therapy

Nanomedicine: Nanotechnology, Biology, and Medicine

Elsevier 


Author of new article
Expected publication date
Estimated size of new
article (number of pages)
Elsevier VAT number
Price
VAT/Local Sales Tax

Total

Terms and Conditions

\author{
Hu Yang \\ Jan 2016 \\ 10 \\ GB 494627212 \\ 0.00 USD \\ 0.00 USD / 0.00 GBP
}

\subsection{USD}

\section{INTRODUCTION}

1. The publisher for this copyrighted material is Elsevier. By clicking "accept" in connection with completing this licensing transaction, you agree that the following terms and conditions apply to this transaction (along with the Billing and Payment terms and conditions established by Copyright Clearance Center, Inc. ("CCC"), at the time that you opened your Rightslink account and that are available at any time at http://myaccount.copyright.com).

\section{GENERAL TERMS}

2. Elsevier hereby grants you permission to reproduce the aforementioned material subject to the terms and conditions indicated. 3. Acknowledgement: If any part of the material to be used (for example, figures) has appeared in our publication with credit or acknowledgement to another source, permission must also be sought from that source. If such permission is not obtained then that material may not be included in your publication/copies. Suitable acknowledgement to the source must be made, either as a footnote or in a reference list at the end of your publication, as follows:

"Reprinted from Publication title, Vol /edition number, Author(s), Title of article / title of chapter, Pages No., Copyright (Year), with permission from Elsevier [OR APPLICABLE SOCIETY COPYRIGHT OWNER]." Also Lancet special credit - "Reprinted from The Lancet, Vol. number, Author(s), Title of article, Pages No., Copyright (Year), with permission from Elsevier."

4. Reproduction of this material is confined to the purpose and/or media for which permission is hereby given.

5. Altering/Modifying Material: Not Permitted. However figures and illustrations may be altered/adapted minimally to serve your work. Any other abbreviations, additions, deletions and/or any other alterations shall be made only with prior written authorization of Elsevier Ltd. (Please contact Elsevier at permissions@elsevier.com)

6. If the permission fee for the requested use of our material is waived in this instance, please be advised that your future requests for Elsevier materials may attract a fee.

7. Reservation of Rights: Publisher reserves all rights not specifically granted in the combination of (i) the license details provided by you and accepted in the course of this licensing transaction, (ii) these terms and conditions and (iii) CCC's Billing and Payment terms and conditions.

8. License Contingent Upon Payment: While you may exercise the rights licensed immediately upon issuance of the license at the end of the licensing process for the transaction, provided that you have disclosed complete and accurate details of your proposed use, no license is finally effective unless and until full payment is received from you (either by publisher or by CCC) as provided in CCC's Billing and Payment terms and conditions. If full payment is not received on a timely basis, then any license preliminarily granted shall be deemed automatically revoked and shall be void as if never granted. Further, in the event that you breach any of these terms and conditions or any of CCC's Billing and Payment terms and conditions, the license is automatically revoked and shall be void as if never granted. Use of materials as described in a revoked license, as well as any use of the materials beyond the scope of an unrevoked license, may constitute copyright infringement and publisher reserves the right to take any and all action to protect its copyright in the materials.

9. Warranties: Publisher makes no representations or warranties with respect to the licensed material.

10. Indemnity: You hereby indemnify and agree to hold harmless publisher and CCC, and their respective officers, directors, employees and agents, from and against any and all claims arising out of your use of the licensed material other than as specifically authorized pursuant to this license.

11. No Transfer of License: This license is personal to you and may not be sublicensed, assigned, or transferred by you to any other person without publisher's written permission.

12. No Amendment Except in Writing: This license may not be amended except in a writing signed by both parties (or, in the case of publisher, by CCC on publisher's behalf).

13. Objection to Contrary Terms: Publisher hereby objects to any terms contained in any purchase order, acknowledgment, check endorsement or other writing prepared by you, which terms are inconsistent with these terms and conditions or CCC's Billing and Payment terms and conditions. These terms and conditions, together with CCC's Billing and Payment terms and conditions (which are incorporated herein), comprise the entire agreement between you and publisher (and CCC) concerning this licensing transaction. In the event of any conflict between your obligations established by these terms and conditions and those established by CCC's Billing and Payment terms and conditions, these terms and conditions shall control.

14. Revocation: Elsevier or Copyright Clearance Center may deny the permissions described in this License at their sole discretion, for any reason or no reason, with a full refund payable to you. Notice of such denial will be made using the contact 
information provided by you. Failure to receive such notice will not alter or invalidate the denial. In no event will Elsevier or Copyright Clearance Center be responsible or liable for any costs, expenses or damage incurred by you as a result of a denial of your permission request, other than a refund of the amount(s) paid by you to Elsevier and/or Copyright Clearance Center for denied permissions.

\section{LIMITED LICENSE}

The following terms and conditions apply only to specific license types:

15. Translation: This permission is granted for non-exclusive world English rights only unless your license was granted for translation rights. If you licensed translation rights you may only translate this content into the languages you requested. A professional translator must perform all translations and reproduce the content word for word preserving the integrity of the article.

16. Posting licensed content on any Website: The following terms and conditions apply as follows: Licensing material from an Elsevier journal: All content posted to the web site must maintain the copyright information line on the bottom of each image; $A$ hyper-text must be included to the Homepage of the journal from which you are licensing at http://www.sciencedirect.com/science /journal/xxxxx or the Elsevier homepage for books at http://www.elsevier.com; Central Storage: This license does not include permission for a scanned version of the material to be stored in a central repository such as that provided by Heron/XanEdu. Licensing material from an Elsevier book: A hyper-text link must be included to the Elsevier homepage at http://www.elsevier.com . All content posted to the web site must maintain the copyright information line on the bottom of each image.

Posting licensed content on Electronic reserve: In addition to the above the following clauses are applicable: The web site must be password-protected and made available only to bona fide students registered on a relevant course. This permission is granted for 1 year only. You may obtain a new license for future website posting.

17. For journal authors: the following clauses are applicable in addition to the above:

Preprints:

A preprint is an author's own write-up of research results and analysis, it has not been peer-reviewed, nor has it had any other value added to it by a publisher (such as formatting, copyright, technical enhancement etc.).

Authors can share their preprints anywhere at any time. Preprints should not be added to or enhanced in any way in order to appear more like, or to substitute for, the final versions of articles however authors can update their preprints on arXiv or RePEc with their Accepted Author Manuscript (see below).

If accepted for publication, we encourage authors to link from the preprint to their formal publication via its DOI. Millions of researchers have access to the formal publications on ScienceDirect, and so links will help users to find, access, cite and use the best available version. Please note that Cell Press, The Lancet and some society-owned have different preprint policies. Information on these policies is available on the journal homepage.

Accepted Author Manuscripts: An accepted author manuscript is the manuscript of an article that has been accepted for publication and which typically includes author-incorporated changes suggested during submission, peer review and editor-author communications.

Authors can share their accepted author manuscript:

- immediately

viaptheir non-commercial person homepage or blog

byaupdating a preprint in arXiv or RePEc with the accepted manuscript

viaptheir research institute or institutional repository for internal institutional uses or as part of an invitation-only research collaboration work-group

directly by providing copies to their students or to research collaborators for their personal use

foroprivate scholarly sharing as part of an invitation-only work group on commercial sites with which Elsevier has an agreement

- $\quad$ after the embargo period vianon-commercial hosting platforms such as their institutional repository viapcommercial sites with which Elsevier has an agreement

In all cases accepted manuscripts should:

- $\quad$ link to the formal publication via its DOI

- $\quad$ bear a CC-BY-NC-ND license - this is easy to do

- $\quad$ if aggregated with other manuscripts, for example in a repository or other site, be shared in alignment with our hosting policy not be added to or enhanced in any way to appear more like, or to substitute for, the published journal article.

Published journal article (JPA): A published journal article (PJA) is the definitive final record of published research that appears or will appear in the journal and embodies all value-adding publishing activities including peer review co-ordination, copy-editing, formatting, (if relevant) pagination and online enrichment.

Policies for sharing publishing journal articles differ for subscription and gold open access articles: 
Subscription Articles: If you are an author, please share a link to your article rather than the full-text. Millions of researchers have access to the formal publications on ScienceDirect, and so links will help your users to find, access, cite, and use the best available version.

Theses and dissertations which contain embedded PJAs as part of the formal submission can be posted publicly by the awarding institution with DOI links back to the formal publications on ScienceDirect.

If you are affiliated with a library that subscribes to ScienceDirect you have additional private sharing rights for others' research accessed under that agreement. This includes use for classroom teaching and internal training at the institution (including use in course packs and courseware programs), and inclusion of the article for grant funding purposes.

Gold Open Access Articles: May be shared according to the author-selected end-user license and should contain a CrossMark

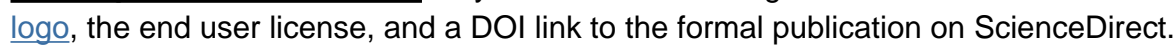

Please refer to Elsevier's posting policy for further information.

18. For book authors the following clauses are applicable in addition to the above: Authors are permitted to place a brief summary of their work online only. You are not allowed to download and post the published electronic version of your chapter, nor may you scan the printed edition to create an electronic version. Posting to a repository: Authors are permitted to post a summary of their chapter only in their institution's repository.

19. Thesis/Dissertation: If your license is for use in a thesis/dissertation your thesis may be submitted to your institution in either print or electronic form. Should your thesis be published commercially, please reapply for permission. These requirements include permission for the Library and Archives of Canada to supply single copies, on demand, of the complete thesis and include permission for Proquest/UMI to supply single copies, on demand, of the complete thesis. Should your thesis be published commercially, please reapply for permission. Theses and dissertations which contain embedded PJAs as part of the formal submission can be posted publicly by the awarding institution with DOI links back to the formal publications on ScienceDirect.

\section{Elsevier Open Access Terms and Conditions}

You can publish open access with Elsevier in hundreds of open access journals or in nearly 2000 established subscription journals that support open access publishing. Permitted third party re-use of these open access articles is defined by the author's choice of Creative Commons user license. See our open access license policy for more information.

Terms \& Conditions applicable to all Open Access articles published with Elsevier:

Any reuse of the article must not represent the author as endorsing the adaptation of the article nor should the article be modified in such a way as to damage the author's honour or reputation. If any changes have been made, such changes must be clearly indicated.

The author(s) must be appropriately credited and we ask that you include the end user license and a DOI link to the formal publication on ScienceDirect.

If any part of the material to be used (for example, figures) has appeared in our publication with credit or acknowledgement to another source it is the responsibility of the user to ensure their reuse complies with the terms and conditions determined by the rights holder.

Additional Terms \& Conditions applicable to each Creative Commons user license:

CC BY: The CC-BY license allows users to copy, to create extracts, abstracts and new works from the Article, to alter and revise the Article and to make commercial use of the Article (including reuse and/or resale of the Article by commercial entities), provided the user gives appropriate credit (with a link to the formal publication through the relevant DOI), provides a link to the license, indicates if changes were made and the licensor is not represented as endorsing the use made of the work. The full details of the license are available at http://creativecommons.org/licenses/by/4.0.

CC BY NC SA: The CC BY-NC-SA license allows users to copy, to create extracts, abstracts and new works from the Article, to alter and revise the Article, provided this is not done for commercial purposes, and that the user gives appropriate credit (with a link to the formal publication through the relevant DOI), provides a link to the license, indicates if changes were made and the licensor is not represented as endorsing the use made of the work. Further, any new works must be made available on the same conditions. The full details of the license are available at http://creativecommons.org/licenses/by-nc-sa/4.0.

CC BY NC ND: The CC BY-NC-ND license allows users to copy and distribute the Article, provided this is not done for commercial purposes and further does not permit distribution of the Article if it is changed or edited in any way, and provided the user gives appropriate credit (with a link to the formal publication through the relevant DOI), provides a link to the license, and that the licensor is not represented as endorsing the use made of the work. The full details of the license are available at http://creativecommons.org/licenses/by-nc-nd/4.0. Any commercial reuse of Open Access articles published with a CC BY NC SA or CC BY NC ND license requires permission from Elsevier and will be subject to a fee.

Commercial reuse includes:

- Associating advertising with the full text of the Article

- $\quad$ Charging fees for document delivery or access

- Article aggregation

- $\quad$ Systematic distribution via e-mail lists or share buttons 
Posting or linking by commercial companies for use by customers of those companies.

20. Other Conditions:

v1.8

Questions? customercare@copyright.com or +1-855-239-3415 (toll free in the US) or +1-978-646-2777. 
Figure 4 was cited from an open access article.

Avidity Mechanism of Dendrimer-Folic Acid Conjugates

Mallory A. van Dongen†, Justin E. Silpe $\ddagger$, Casey A. Dougherty†, Ananda Kumar Kanduluru //,

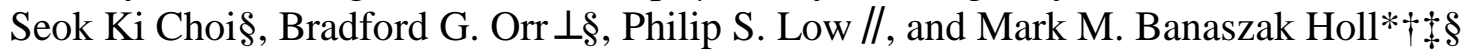

${ }^{\dagger}$ Department of Chemistry and ${ }^{\perp}$ Department of Physics, ${ }^{\ddagger}$ Program in Macromolecular Sciences and Engineering, and ${ }^{\S}$ Michigan Nanotechnology Institute for Medicine and Biological Sciences, University of Michigan, Ann Arbor, Michigan 48019, United States

" Department of Chemistry, Purdue University, West Lafayette, Indiana 47907, United States Mol. Pharmaceutics, 2014, 11 (5), pp 1696-1706

DOI: $10.1021 / \mathrm{mp} 5000967$

Publication Date (Web): April 11, 2014

Copyright (C) 2014 American Chemical Society

ACS AuthorChoice - This is an open access article published under an ACS AuthorChoice License, which permits copying and redistribution of the article or any adaptations for noncommercial purposes. 


\section{Figure 5 was taken from an open-access article}

Conniot, J.; Silva, J. M.; Fernandes, J. G.; Silva, L. C.; Gaspar, R.; Brocchini, S.; Florindo, H. F.; Barata, T. S. Cancer immunotherapy: nanodelivery approaches for immune cell targeting and tracking. Front Chem 2014, 2, 105.

Copyright (C) 2014 Conniot, Silva, Fernandes, Silva, Gaspar, Brocchini, Florindo and Barata. This is an open-access article distributed under the terms of the Creative Commons Attribution License (CC BY). The use, distribution or reproduction in other forums is permitted, provided the original author(s) or licensor are credited and that the original publication in this journal is cited, in accordance with accepted academic practice. No use, distribution or reproduction is permitted which does not comply with these terms. 